\title{
Identification of surface composition and chemical states in composites comprised of phases with fluorite and perovskite structures by X-ray photoelectron spectroscopy
}

\author{
Elena Yu Konysheva ${ }^{\mathrm{a}, \mathrm{b}, *}$, Stephen M. Francis ${ }^{\mathrm{a}}$ \\ a School of Chemistry, University of St Andrews, St Andrews, Fife, KY16 9ST, UK \\ ${ }^{\mathrm{b}}$ Ural Federal University, 51 Lenin Av., Ekaterinburg 620083, Russia
}

\section{A R T I C L E I N F O}

\section{Article history:}

Received 27 July 2012

Received in revised form

16 November 2012

Accepted 13 December 2012

Available online 21 December 2012

\section{Keywords:}

X-ray photoelectron spectroscopy (XPS)

Surface composition

Composites with perovskite and fluorite

structures

Oxidation state of cerium cations

Binding energy

\begin{abstract}
A B S T R A C T
X-ray photoelectron spectroscopy (XPS) has been used to explore the cation rearrangement between the surface and bulk of grains and the surface chemical states of $\mathrm{Ce}, \mathrm{Mn}, \mathrm{Co}, \mathrm{Sr}$, and $\mathrm{O}$ ions in the single phase $\mathrm{CeO}_{2}$-based solid solutions and in the two phase $(100-x) \mathrm{La}_{0.6} \mathrm{Sr}_{0.4} \mathrm{CoO}_{3}-x \mathrm{CeO}_{2}$ (LSCC $x$ ) and $(100-x) \mathrm{La}_{0.8} \mathrm{Sr}_{0.2} \mathrm{MnO}_{3}-x \mathrm{CeO}_{2}$ (LSMC $x$ ) composites. The well-resolved Ce $3 d_{5 / 2}$ and $\mathrm{Ce} 3 d_{3 / 2}$ spin-orbit components were determined to study the $\mathrm{Ce}^{4+}$ to $\mathrm{Ce}^{3+}$ electronic transition at the surface. The surface of the LSCC $x$ and LSMC $x(x=8-40 \mathrm{~mol} \%)$ composites is depleted in cerium. Both $\mathrm{Ce}^{4+}$ and $\mathrm{Ce}^{3+}$ cations were revealed. The surface fraction of $\mathrm{Ce}^{4+}$ cations increases with the rise in $\mathrm{CeO}_{2}$ content in both systems, but it is higher by about a factor of two in the LSCC composites. A strong enrichment of the surface by Co cations was observed for the composites LSCC $x$ ( $x=8-40 \mathrm{~mol} \%$ ), implying that the presence of cerium could facilitate the Co surface segregation. A slight Sr surface enrichment compared to the nominal stoichiometry was found for $\mathrm{La}_{0.6} \mathrm{Sr}_{0.4} \mathrm{CoO}_{3}, \mathrm{CeO}_{2}$-based solid solutions, LSCC57, and LSMC $x(x=10-57)$ composites. In contrast, the surface of the LSCC $x(x=10-37)$ composites is slightly depleted in strontium cations. The $\mathrm{O} 1 \mathrm{~s}$ spectra of the LSCC and LSMC composites contain several contributions associated with the lattice oxygen related to the phases with the perovskite and fluorite structures as well as with different surface states. Their contributions vary with $\mathrm{CeO}_{2}$ content and a chemical origin of the transition metal cations on the B-site in the perovskite structure. The $\mathrm{Ce}_{2}\left(\mathrm{CO}_{3}\right)_{3}$-based phase seems to exist at the surface of grains and crystallites in the LSCC57 and LSCM composites.
\end{abstract}

(c) 2012 Elsevier B.V. All rights reserved.

\section{Introduction}

Complex materials containing transition metal and cerium cations have been considered as catalysts, electrodes in fuel cells, and batteries [1-12]. A high activity with respect to a certain catalytic or electrode process could relate to an optimal surface concentration of Ce cations and their involvement in the reversible redox cycle $\left(\mathrm{Ce}^{3+} \leftrightarrow \mathrm{Ce}^{4+}\right)[13]$. Stoichiometric defects such as oxygen vacancies, which form during reduction of cerium cations, and their mobility on the surface are of great importance for catalytic activity [14-16]. X-ray photoelectron spectroscopy (XPS) is the

\footnotetext{
* Corresponding author. Present address: Department of Chemistry, Xi'an Jiaotong-Liverpool University, Suzhou Dushu Lake Higher Education Town, Suzhou Industrial Park, Suzhou, Jiangsu Province 215123, China. Tel.: +86 512 88161435; fax: +8651281880440.

E-mail addresses: elena.konysheva@googlemail.com, elena.konysheva@xjtlu.edu.cn (E.Y. Konysheva).
}

method that allows monitoring changes in the local environment of ions and their oxidations states [17]. The surface chemical states of Ce cations have been explored so far preferably for undoped $\mathrm{CeO}_{2}$ [18-23], $\mathrm{CeO}_{2}$-based solid solutions [24-26], and composites composed of $\mathrm{CeO}_{2}$ and transition metals or their oxides [27-34]. It was shown that properties of composite materials (redox properties, formation of surface and bulk oxygen vacancies, oxygen storage and release) can be optimised through the variation of the $\mathrm{CeO}_{2} / \mathrm{Me}\left(\mathrm{Me}_{x} \mathrm{O}_{y}\right)$ ratios.

In the present work we explore the evolution of the surface composition and chemical states in complex composite systems initially composed of a perovskite phase with transition metal cations on the B-sites $\left(\mathrm{La}_{0.6} \mathrm{Sr}_{0.4} \mathrm{CoO}_{3}\right.$ or $\left.\mathrm{La}_{0.8} \mathrm{Sr}_{0.2} \mathrm{MnO}_{3}\right)$ and cerium oxide with fluorite structure. The perovskite-fluorite interface in composite cathodes in fuel cells is responsible for oxygen sorption and reduction, surface mobility of oxygen vacancies, fast oxygen ion exchange between the surface and bulk of grains, and for optimum distribution of catalysts over surface (which depends on wetting characteristics of the interface) [8-12]. A recent computational 
study showed that transition metal cations are responsible for the electrocatalytic activity for oxygen reduction [35], suggesting that a high surface concentration of transition metal cations could facilitate surface processes. XPS and Auger electron spectroscopy studies carried out on perovskites, however, revealed that the surface concentration of the transition metal cations in the cation stoichiometric perovskites is either the same as in the volume of crystallites or lower [36-41]. It is not clear whether the presence of a second phase (cerium oxide) would change the surface concentration of transition metal cations or not. The existence of both $\mathrm{Mn}^{(4+/ 3+/ 2+)}$ and $\mathrm{Co}^{(4+/ 3+/ 2+)}$ cations in different oxidation states, their ability to be involved in the reversible redox cycle (in particular Co cations) and to be dissolved in the fluorite structure would influence or not the oxidation state of Ce cations at the surface. To address these and other issues we consider our materials in terms of the core-shell model, where the bulk structural parameters of perovskites and cerium oxide were analysed by X-ray powder diffraction (XRD), whereas X-ray photoelectron spectroscopy (XPS) measurements provided summary information on the surface composition and chemical states of cations and oxygen ions at the surface and interfaces.

\section{Experimental}

The initial perovskites $\mathrm{La}_{0.6} \mathrm{Sr}_{0.4} \mathrm{CoO}_{3}$ (LSC) and $\mathrm{La}_{0.8} \mathrm{Sr}_{0.2} \mathrm{MnO}_{3}$ (LSM) were produced by combustion spray pyrolysis and supplied by PRAXAIR Inc., USA. $\mathrm{CeO}_{2}(99.9 \%)$ was delivered by ACROS ORGANICS (New Jersey, USA) and was calcined at $1000^{\circ} \mathrm{C}$ for $5 \mathrm{~h}$ to remove adsorbed water. Further, compositions in the following series $(100-x) \mathrm{LSC} \cdot x \mathrm{CeO}_{2}(\mathrm{LSCC} x)$ with $x=8,10,25,37,57 \mathrm{~mol} \%$ and $(100-x) \mathrm{LSM} \cdot x \mathrm{CeO}_{2}(\mathrm{LSMC} x)$ with $x=2,10,25,36,57 \mathrm{~mol} \%$ were obtained by mechanical mixing of LSC or LSM and $\mathrm{CeO}_{2}$ in relevant ratios, followed by calcination in air at $1350^{\circ} \mathrm{C}$ for $5 \mathrm{~h}$. The initial phases (LSC, LSM, and $\mathrm{CeO}_{2}$ ) were also calcined under the same conditions. The $\mathrm{Ce}_{0.905} \mathrm{La}_{0.028} \mathrm{Sr}_{0.019} \mathrm{Co}_{0.048} \mathrm{O}_{2-\delta}$ and $\mathrm{Ce}_{0.808} \mathrm{La}_{0.058} \mathrm{Sr}_{0.038} \mathrm{Co}_{0.096} \mathrm{O}_{2-\delta}$ single phase solid solutions were fabricated through mixing of $\mathrm{CeO}_{2}$ with 5 and $10.6 \mathrm{~mol} \%$ $\mathrm{La}_{0.6} \mathrm{Sr}_{0.4} \mathrm{CoO}_{3}$, respectively, followed by calcination in air at $1350{ }^{\circ} \mathrm{C}$ for $5 \mathrm{~h}$.

X-ray photoelectron spectroscopy (XPS) was applied to study the surface composition and the chemical states of ions in the LSCC and LSMC series. The survey spectra and detailed spectra (were recorded on the polished pellets (SiC-paper 2500 grits) with an ESCALAB II spectrometer (V.G., UK) for the LSCC system using nonchromatic $\mathrm{Al} \mathrm{K}_{\alpha}(h v=1486.4 \mathrm{eV})$ radiation and a XPS $5600 \mathrm{spec}-$ trometer (Physical Electronic, USA) for the LSMC system using monochromatic $\mathrm{Al} \mathrm{K} \mathrm{K}_{\alpha}(h v=1486.4 \mathrm{eV})$ radiation. Data were collected at a take-off angle of $45^{\circ}$, allowing the characterisation of the surface and the near surface region. The spectra were analysed with CasaXPS software. The binding energies $(B E)$ are referenced to the $\mathrm{C} 1 \mathrm{~s}$ peak at $284.6 \mathrm{eV}$ and given with a precision of $0.1-0.2 \mathrm{eV}$. The atomic concentrations of elements (relative error: $\pm 15 \%$ ) were calculated from the fitted peak areas using appropriate atomic sensitivity factors. X-ray powder diffraction (XRD) data were recorded in air at room temperature in transmission mode on a Stoe Stadi-P diffractometer with $\mathrm{Cu}_{\alpha}$ radiation (Stoe \& Cie GmbH, Germany). The diffraction spectra were registered in the angular range of $15 \leq 2 \Theta \leq 96^{\circ}$, with a step size of $0.1^{\circ}$, and a recording time of $70 \mathrm{~s}$ for each step. Si powder (Alfa Aesar, Karlsruhe, Germany) was used as the external standard for the calibration of the diffractometer. The diffraction data were refined by the Rietveld method [42], using the program Generalized Structure Analysis System (GSAS) [43], to identify the crystal structure of each constituent phase in the composites investigated.

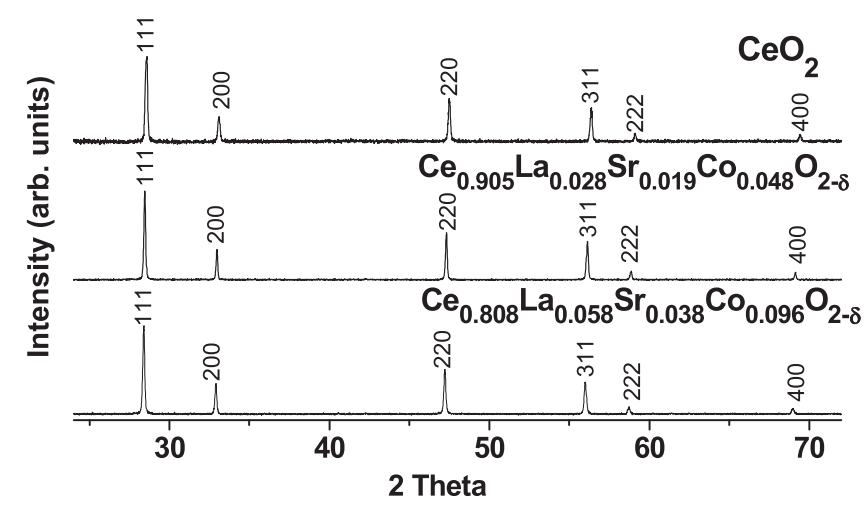

Fig. 1. XRD patterns of undoped $\mathrm{CeO}_{2}, \mathrm{Ce}_{0.905} \mathrm{La}_{0.028} \mathrm{Sr}_{0.019} \mathrm{Co}_{0.048} \mathrm{O}_{2-\delta}$, and $\mathrm{Ce}_{0.808} \mathrm{La}_{0.058} \mathrm{Sr}_{0.038} \mathrm{Co}_{0.096} \mathrm{O}_{2-\delta}$ single phase compositions.

\section{Results and discussion}

\subsection{Pure and modified cerium oxides with fluorite structure} calcined at $1350^{\circ} \mathrm{C}$ in air

The XRD patterns of pure and doped cerium oxide are presented in Fig. 1. Pure $\mathrm{CeO}_{2}$, the single phase solid solutions $\mathrm{Ce}_{0.905} \mathrm{La}_{0.028} \mathrm{Sr}_{0.019} \mathrm{Co}_{0.048} \mathrm{O}_{2-\delta}$ and $\mathrm{Ce}_{0.808} \mathrm{La}_{0.058} \mathrm{Sr}_{0.038} \mathrm{Co}_{0.096} \mathrm{O}_{2-\delta}$ have the fluorite structure (space group $F m \overline{3} m$, no. 225) [44-46]. The lattice parameter of undoped $\mathrm{CeO}_{2}$ is 5.4103(9) $\AA$ [46]. On multi-cation doping, the lattice parameter of the modified cerium oxides increases up to $5.4258(1) \AA$ and 5.4420(2) $\AA$, respectively, for $\mathrm{Ce}_{0.905} \mathrm{La}_{0.028} \mathrm{Sr}_{0.019} \mathrm{Co}_{0.048} \mathrm{O}_{2-\delta}$ and $\mathrm{Ce}_{0.808} \mathrm{La}_{0.058} \mathrm{Sr}_{0.038} \mathrm{Co}_{0.096} \mathrm{O}_{2-\delta}$ [46]. Fig. 2 illustrates the survey spectra of pure and multi-cation doped cerium oxides after calcination in air at $1350^{\circ} \mathrm{C}$. Their surface compositions derived from the XPS measurements are presented in Table 1. The surface composition of pure $\mathrm{CeO}_{2}$ measured on two different instruments is in a good accord although it differs from the bulk composition (33.3 at.\% Ce and 66.7 at.\% O). This suggests a strong influence of high-temperature treatment on the surface composition of grains and crystallites within the top several nanometres. In $\mathrm{Ce}_{0.905} \mathrm{La}_{0.028} \mathrm{Sr}_{0.019} \mathrm{Co}_{0.048} \mathrm{O}_{2-\delta}$ and $\mathrm{Ce}_{0.808} \mathrm{La}_{0.058} \mathrm{Sr}_{0.038} \mathrm{Co}_{0.096} \mathrm{O}_{2-\delta}$ single phase solid solutions, only $\mathrm{Sr}$ cations were revealed at the surface, indicating that La and Co cations dissolve entirely into the fluorite lattice. Unfortunately, it was impossible to identify the $\mathrm{Sr}$ surface states in the single phase solid solutions due to a strong

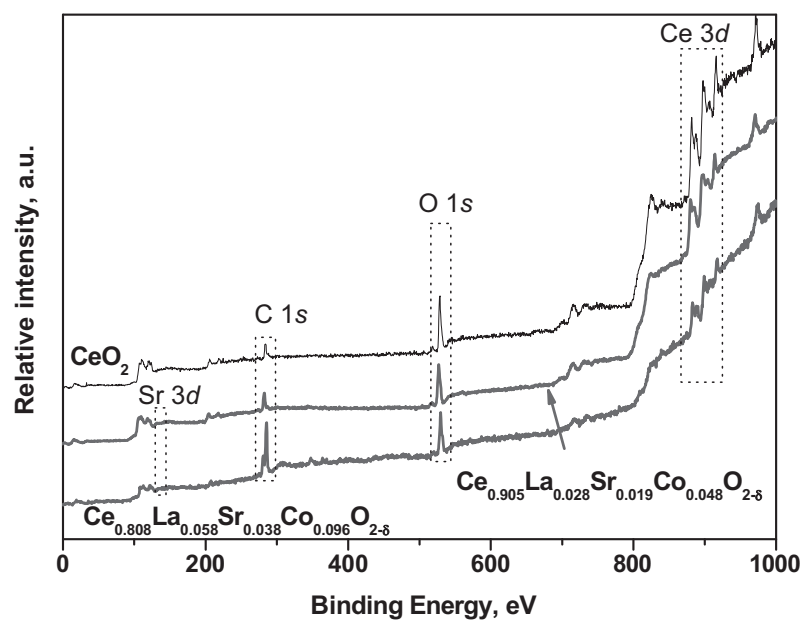

Fig. 2. Survey spectra of undoped $\mathrm{CeO}_{2}, \mathrm{Ce}_{0.905} \mathrm{La}_{0.028} \mathrm{Sr}_{0.019} \mathrm{Co}_{0.048} \mathrm{O}_{2-\delta}$, and $\mathrm{Ce}_{0.808} \mathrm{La}_{0.058} \mathrm{Sr}_{0.038} \mathrm{Co}_{0.096} \mathrm{O}_{2-\delta}$ single phase compositions. 
Table 1

Surface atomic composition derived from XPS for pure and multi-cation doped cerium oxides with fluorite structure calcined at $1350{ }^{\circ} \mathrm{C}$ for $5 \mathrm{~h}$ in air.

\begin{tabular}{|c|c|c|c|c|c|c|c|}
\hline \multirow[t]{2}{*}{ Composition } & \multirow[t]{2}{*}{ Instrument } & \multicolumn{5}{|c|}{ Atomic concentration, at. $\%^{\mathrm{a}}$} & \multirow[t]{2}{*}[\mathrm{Ce}^{4+}]{$/\left[\mathrm{Ce}^{3+}\right]$ atomic ratio } \\
\hline & & $\mathrm{Ce}$ & $\mathrm{Sr}$ & La & Co & $\mathrm{O}$ & \\
\hline \multirow[t]{2}{*}{$\mathrm{CeO}_{2}$} & ESCALAB II & 21.7 & - & - & - & 78.3 & 4.5 \\
\hline & XPS 5600 & 18.6 & - & - & - & 81.4 & 3.6 \\
\hline $\mathrm{Ce}_{0.905} \mathrm{La}_{0.028} \mathrm{Sr}_{0.019} \mathrm{Co}_{0.048} \mathrm{O}_{2-\delta}$ & ESCALAB II & 9.8 & 1.1 & - & - & 89.1 & 4.5 \\
\hline $\mathrm{Ce}_{0.808} \mathrm{La}_{0.058} \mathrm{Sr}_{0.038} \mathrm{Co}_{0.096} \mathrm{O}_{2-\delta}$ & ESCALAB II & 24.0 & 7.5 & - & - & 68.5 & 13.2 \\
\hline
\end{tabular}

a Relative error is $\pm 15 \%$.

differential charging in the detailed $\mathrm{Sr} 3 d$ (by $\sim 10 \mathrm{eV}$ ) and $\mathrm{O}$ $1 s$ (by $\sim 8-10 \mathrm{eV}$ ) spectra, which were collected after the recording of the Ce $3 d$ detailed spectra. Incorporation of lanthanum into the fluorite structure of $\mathrm{CeO}_{2}$ should be accompanied by an increase in the lattice parameter or unit cell volume as was observed for the single phase $\mathrm{Ce}_{0.905} \mathrm{La}_{0.028} \mathrm{Sr}_{0.019} \mathrm{Co}_{0.048} \mathrm{O}_{2-\delta}$ and $\mathrm{Ce}_{0.808} \mathrm{La}_{0.058} \mathrm{Sr}_{0.038} \mathrm{Co}_{0.096} \mathrm{O}_{2-\delta}$. The $\mathrm{Sr}$ surface segregation may be explained through the largest difference in the ionic radii between the host $\mathrm{Ce}^{4+}$ cations $\left(r^{\mathrm{VIII}}=0.97 \AA\right)$ and the doping $\mathrm{Sr}^{2+}$ cations $\left(r^{\mathrm{VIII}}=1.26 \AA\right)$ compared to $\mathrm{La}^{3+}\left(r^{\mathrm{VIII}}=1.16 \AA\right)$ and $\mathrm{Co}^{2+}$ $\left(r^{\mathrm{VIII}}=0.90 \AA\right)$ cations [47]. These results are slightly surprising for $\mathrm{Sr}$ as up to $9 \mathrm{~mol} \% \mathrm{SrO}$ can dissolve individually in the fluorite structure of $\mathrm{CeO}_{2}$ [48]. For other cations it is known that up to $50 \mathrm{~mol} \%$ $\mathrm{La}_{2} \mathrm{O}_{3}[49,50]$ and up to $5 \mathrm{~mol} \%$ Co containing oxides [51,52] can dissolve individually in the fluorite structure of $\mathrm{CeO}_{2}$ with the formation of solid solutions. Dissolution of a high fraction of Co cations into the fluorite structure of $\mathrm{Ce}_{0.808} \mathrm{La}_{0.058} \mathrm{Sr}_{0.038} \mathrm{Co}_{0.096} \mathrm{O}_{2-\delta}$ was also slightly unexpected. The results imply that the multi-cation doping approach is more intricate and simultaneous dissolution of different cations within the fluorite structure will not always obey their individual dissolution limits. It seems that at first the dissolution of cations with the lowest difference in the ionic radii between the host and the doping cations takes place. In our case, the difference in the ionic radii between $\mathrm{Ce}^{4+}$ (as the host cation) and $\mathrm{La}^{3+}, \mathrm{Co}^{2+}, \mathrm{Sr}^{2+}$ (as dopants) increases in the following way (the numbers in the round brackets are the modulus of the difference in the values of ionic radii): $\mathrm{Co}^{2+}(0.07 \AA) \rightarrow \mathrm{La}^{3+}$ $(0.19 \AA) \rightarrow \mathrm{Sr}^{2+}(0.27 \AA)$. Notice that the appearance of $\mathrm{Ce}^{3+}$ cations $\left(r^{\mathrm{VIII}}=1.14 \AA\right)$ within the fluorite structure would change tendency: $\mathrm{La}^{3+}(0.02 \AA) \rightarrow \mathrm{Sr}^{2+}(0.12 \AA) \rightarrow \mathrm{Co}^{2+}(0.24 \AA)$.

There are two features in the $\mathrm{C} 1 s$ spectra of pure $\mathrm{CeO}_{2}$, the single phase solid solutions $\mathrm{Ce}_{0.905} \mathrm{La}_{0.028} \mathrm{Sr}_{0.019} \mathrm{Co}_{0.048} \mathrm{O}_{2-\delta}$ and $\mathrm{Ce}_{0.808} \mathrm{La}_{0.058} \mathrm{Sr}_{0.038} \mathrm{Co}_{0.096} \mathrm{O}_{2-\delta}$. Apart from the peak at $284.6 \mathrm{eV}$ that corresponds to the adventitious carbon, the peak at $288.4-288.7 \mathrm{eV}$ was observed in the $\mathrm{C}$ $1 \mathrm{~s}$ spectra of $\mathrm{CeO}_{2}, \quad \mathrm{Ce}_{0.905} \mathrm{La}_{0.028} \mathrm{Sr}_{0.019} \mathrm{Co}_{0.048} \mathrm{O}_{2-\delta}$ and $\mathrm{Ce}_{0.808} \mathrm{La}_{0.058} \mathrm{Sr}_{0.038} \mathrm{Co}_{0.096} \mathrm{O}_{2-\delta}$. The feature at $288.4-288.7 \mathrm{eV}$ in pure and doped cerium oxides may be related to several functional groups or compounds containing $\mathrm{Ce}, \mathrm{C}$, $\mathrm{O}$ and/or $\mathrm{Sr}$ (only for $\mathrm{Ce}_{0.905} \mathrm{La}_{0.028} \mathrm{Sr}_{0.019} \mathrm{Co}_{0.048} \mathrm{O}_{2-\delta}$ and $\mathrm{Ce}_{0.808} \mathrm{La}_{0.058} \mathrm{Sr}_{0.038} \mathrm{Co}_{0.096} \mathrm{O}_{2-\delta}$.): carbonyl groups (C $1 \mathrm{~s}$ $B E=288.1-288.3 \mathrm{eV})[53-55], \mathrm{Ce}_{2}\left(\mathrm{CO}_{3}\right)_{3} \cdot 8 \mathrm{H}_{2} \mathrm{O}(\mathrm{C} 1 \mathrm{~s} \mathrm{BE}=288.7 \mathrm{eV})$ $[56,57]$ or $\mathrm{SrCO}_{3} \cdot(\mathrm{C} 1 \mathrm{~s} \mathrm{BE}=288.8 \mathrm{eV})[56,58]$. Because of the strong differential charge observed for $\mathrm{Sr} 3 d(\sim 10 \mathrm{eV})$ and $\mathrm{O} 1 \mathrm{~s}$ spectra $(\sim 10 \mathrm{eV})$, it is difficult to identify more precisely the origin of the features at $288.4-288.7 \mathrm{eV}$.

The Ce $3 d$ spectra of the pure and multi-cation modified cerium oxides are complex (Fig. 3) resulting from the various initial and final states of $\mathrm{Ce}^{3+}$ and $\mathrm{Ce}^{4+}$ cations (Table 2). In general, the Ce $3 d$ spectra can be individually deconvoluted into five pairs of $3 d_{5 / 2}$ and $3 d_{3 / 2}$ spin-orbit components (labelled as $v$ and $u$, respectively) describing the $\mathrm{Ce}^{4+} \leftrightarrow \mathrm{Ce}^{3+}$ electronic transitions [18-23]. According to the literature [18-23], the four intense components $v(B E \sim 882.2 \mathrm{eV}), u(B E \sim 900.8 \mathrm{eV}), v^{\prime \prime l}$ $(B E \sim 898.1 \mathrm{eV}), u^{\prime / l}(B E \sim 916.2 \mathrm{eV})$ as well as the two weaker components $v^{\prime l}(B E \sim 888.8 \mathrm{eV})$ and $u^{\prime l}(B E \sim 906.9 \mathrm{eV})$ can be attributed to $\mathrm{Ce}^{4+}$ cations. For $\mathrm{Ce}^{3+}$ cations, the $v^{\prime}(B E \sim 885.6 \mathrm{eV})$ and $u^{\prime}(B E \sim 903.9 \mathrm{eV})$ components are more intense, whereas the $v_{0}(B E \sim 880.6-881.4 \mathrm{eV})$ and $u_{0}(B E \sim 898.9-899.3 \mathrm{eV})$ components are noticeably weaker and sometimes their contributions in the Ce $3 d$ spectrum can not be clearly distinguished, in particular at a high concentration of $\mathrm{Ce}^{4+}$ cations $[23,26,30]$. In pure and multi-cation doped cerium oxides calcinated at $1350^{\circ} \mathrm{C}$, one can distinguish the contribution of the $v$ and $u$ / peaks to the spectra, suggesting the presence of both $\mathrm{Ce}^{4+}$ (major fraction) and $\mathrm{Ce}^{3+}$ cations. The concentration of $\mathrm{Ce}^{4+}$ and $\mathrm{Ce}^{3+}$ cations in cerium oxide can be estimated as Eqs. (1)-(3) [23], where the $\left[\mathrm{Ce}^{3+}\right]$ and $\left[\mathrm{Ce}^{4+}\right]$ stand for the sums of the integrated peak areas related to their XPS signals respectively:

$\left[\mathrm{Ce}^{4+}\right]=v+v^{/ /}+v^{/ / /}+u+u^{/ /}+u^{/ / /}$

$\left[\mathrm{Ce}^{3+}\right]=v_{0}+v^{\prime}+u_{0}+u^{\prime}$

$\left[\mathrm{Ce}^{4+}\right]=\left[\mathrm{Ce}^{4+}\right] /\left(\left[\mathrm{Ce}^{4+}\right]+\left[\mathrm{Ce}^{3+}\right]\right)$

The estimated ratio of $\mathrm{Ce}^{4+}$ and $\mathrm{Ce}^{3+}$ cations for pure and doped cerium oxides at the surface is presented in Table 1. Results obtained from the XPS measurement of $\mathrm{CeO}_{2-\delta}$ on the different instruments show good correlation. In $\mathrm{Ce}_{0.905} \mathrm{La}_{0.028} \mathrm{Sr}_{0.019} \mathrm{Co}_{0.048} \mathrm{O}_{2-\delta}$ with a relatively low level of multi-cation doping ( $\mathrm{La}, \mathrm{Sr}$, and $\mathrm{Co}$ ), the $\left[\mathrm{Ce}^{4+}\right] /\left[\mathrm{Ce}^{3+}\right]$ atomic ratio remains the same as in $\mathrm{CeO}_{2}$, whereas a drastic increase in the surface concentration of $\mathrm{Ce}^{4+}$ cations is observed in $\mathrm{Ce}_{0.808} \mathrm{La}_{0.058} \mathrm{Sr}_{0.038} \mathrm{Co}_{0.096} \mathrm{O}_{2-\delta}$ (Table 1 ). One may assume that the dissolution of $\mathrm{Co}$ cations up to a certain level can stabilise $\mathrm{Ce}^{4+}$ cations due to the close values of the ionic radii and this could explain the increase in the surface concentration of $\mathrm{Ce}^{4+}$ cations in $\mathrm{Ce}_{0.808} \mathrm{La}_{0.058} \mathrm{Sr}_{0.038} \mathrm{Co}_{0.096} \mathrm{O}_{2-\delta}$.

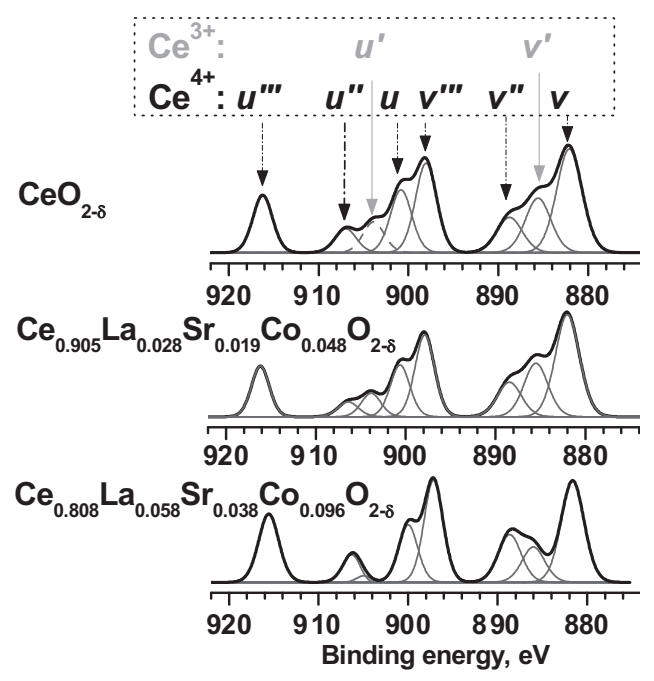

Fig. 3. Curve-fitted $\mathrm{Ce} 3 d$ core level spectra of pure cerium oxide, $\mathrm{Ce}_{0.905} \mathrm{La}_{0.028} \mathrm{Sr}_{0.019} \mathrm{Co}_{0.048} \mathrm{O}_{2-\delta}$, and $\mathrm{Ce}_{0.808} \mathrm{La}_{0.058} \mathrm{Sr}_{0.038} \mathrm{Co}_{0.096} \mathrm{O}_{2-\delta}$ single phase compositions. 
Table 2

Initial states and final states of $\mathrm{Ce}^{4+}$ and $\mathrm{Ce}^{3+}$ cations in the Ce $3 d$ core level spectra $[18,20]$.

\begin{tabular}{|c|c|c|c|c|}
\hline \multirow[t]{2}{*}{ Cations in Cerium oxides } & \multirow[t]{2}{*}{ Initial state } & \multirow[t]{2}{*}{ Final state } & \multicolumn{2}{|c|}{ Peak components } \\
\hline & & & Ce $3 d_{5 / 2}$ & Ce $3 d_{3 / 2}$ \\
\hline \multirow{3}{*}{$\mathrm{Ce}^{4+}\left(\mathrm{CeO}_{2}\right)$} & Ce $3 \mathrm{~d}^{10} 4 \mathrm{f}^{0}-\mathrm{O} 2 \mathrm{p}^{6}$ & Ce $3 d^{9} 4 f^{2}-O 2 p^{4}$ & $v$ & $u$ \\
\hline & Ce $3 d^{10} 4 f^{0}-02 p^{6}$ & Ce $3 d^{9} 4 f^{1}-O 2 p^{5}$ & $v^{\prime \prime}$ & $u^{\prime l}$ \\
\hline & Ce $3 \mathrm{~d}^{10} 4 \mathrm{f}^{0}-\mathrm{O} 2 \mathrm{p}^{6}$ & Ce $3 d^{9} 4 f^{0}-O 2 p^{6}$ & $v^{\prime \prime \prime}$ & $u^{\prime \prime \prime}$ \\
\hline \multirow[t]{2}{*}{$\mathrm{Ce}^{3+}\left(\mathrm{Ce}_{2} \mathrm{O}_{3}\right)$} & Ce $3 d^{10} 4 f^{1}-O 2 p^{6}$ & Ce $3 d^{9} 4 f^{1}-O 2 p^{6}$ & $v^{\prime}$ & $u^{\prime}$ \\
\hline & Ce $3 \mathrm{~d}^{10} 4 \mathrm{f}^{1}-\mathrm{O} 2 \mathrm{p}^{6}$ & Ce $3 d^{9} 4 f^{2}-O 2 p^{5}$ & $v_{0}$ & $u_{0}$ \\
\hline
\end{tabular}

3.2. Surface composition and surface states of Ce cations in the LSCC and LSMC composites consisting of the perovskite phase and modified cerium oxide

Both $\mathrm{La}_{0.6} \mathrm{Sr}_{0.4} \mathrm{CoO}_{3}$ (LSC) and $\mathrm{La}_{0.8} \mathrm{Sr}_{0.2} \mathrm{MnO}_{3}$ (LSM) perovskites exhibit rhombohedral symmetry, space group $R \overline{3} c$ (no. 167) $[39,59,60]$. A solubility limit of $\mathrm{CeO}_{2}$ in the perovskite structure of the LSC and LSM is about $2 \mathrm{~mol} \%$ [39], although a very weak peak, which is close to the $\{111\}$ cubic reflection of $\mathrm{CeO}_{2}$ (JCPDF 34-0394) [44], was observed in the XRD pattern of the LSMC02 recorded in the reflection mode [39]. The LSMC02 was considered as a nearly single phase composition. According to XRD, the LSCC $x$ $(x=8-57 \mathrm{~mol} \%)$ and LSMC $x(x=10-57 \mathrm{~mol} \%)$ are two-phase compositions (Table 3 ). They are composed of the perovskite phase with rhombohedral symmetry (space group $R \overline{3} c$, no. 167) and the modified cerium oxide with fluorite structure (space group $F m \overline{3} m$, no. 225). In contrast to the LSMC $x$ ( $x=10-57 \mathrm{~mol} \%)$ composites, where the lattice parameter of cerium oxide is much closer to that for undoped $\mathrm{CeO}_{2}$, a strong increase in the lattice parameter of cerium oxide was revealed in the LSCC $x(x=8-57$ mol\%) composites, suggesting the dissolution of La, Sr, and Co cations within the fluorite structure. The latest was confirmed by scanning electron microscopy in combination with an energy dispersive X-ray analysis (SEM/EDX) [61]. A non-linear change in the lattice parameters of the perovskite constituent in the LSCC series (Table 3) implies the variation in fractions of $\mathrm{Ce}, \mathrm{La}, \mathrm{Sr}$ and Co cations cross-dissolved at the phase interfaces.

Further we studied the surface compositions and chemical states of ions in the LSCC and LSMC composites fabricated at $1350{ }^{\circ} \mathrm{C}$ in air. Results obtained from the XPS survey spectra (Fig. 4) were compared with the nominal stoichiometry of the composites that was ascribed further in the text as "nominal stoichiometry" (Tables 4 and 5). According to XPS, the Sr surface concentration in the LSC, LSCC57, and LSMC $x(x=2-57)$ is slightly higher than expected, whereas it is lower in the LSCC $x(x=10-37)$ (Tables 4 and 5). In the single phase LSC and LSMC02, the [Sr]/[La] ration is slightly higher compared to the nominal stoichiometry (Fig. 5a) that is typical of the perovskites with transition metal cations on the B-sites [36,38-40]. The same trend was observed for the two-phase compositions in both LSCC and LSMC series. The $[\mathrm{Co}$ or $\mathrm{Mn}] /([\mathrm{La}]+[\mathrm{Sr}])$ ratio is expected to be 1 (Fig. $5 \mathrm{~b})$. According to XPS, the $[\mathrm{Mn}] /([\mathrm{La}]+[\mathrm{Sr}])$ atomic ratio is slightly less than 1 for the LSMC02 and remains the same with further increase in cerium oxide content in the LSMC series $(x=10-36)$. For the LSMC57, the $[\mathrm{Mn}] /([\mathrm{La}]+[\mathrm{Sr}])$ atomic ratio was slightly higher than 1. In contrast, a complex trend was observed in the LSCC series. The surface concentration of Co cations in LSC is lower by about a factor of 3 than the expected value. On increasing the cerium oxide content (up to 8-37 mol\%), the surface of the LSCC compositions becomes enriched in Co by about a factor of 3-5 compared to the nominal stoichiometry. However, the surface concentration of Co cations in the LSCC57 drops and it is less by about a factor of two compared to the nominal ratio (Table 4 and Fig. 5b) independent of whether the measurements were carried out on the pellet with $92 \% \mathrm{rD}$ or on the powders with different fabrication history $\left(S_{\mathrm{BET}}=0.18-0.77 \mathrm{~m}^{2} / \mathrm{g}\right)$ [61]. This could be interpreted as redistribution of Co cations between the surface and bulk of crystallites.

The $[\mathrm{Co}$ or $\mathrm{Mn}]) /[\mathrm{Ce}]$ and $([\mathrm{La}]+[\mathrm{Sr}]+[\mathrm{Co}$ or $\mathrm{Mn}]) /[\mathrm{Ce}]$ atomic ratios estimated from the nominal stoichiometry of the LSCC and LSMC composites change in a non-linear way with the increase in ceria content (Fig. 6). Similar trends were observed from the XPS measurements, but the surface concentration of Ce in the LSCC $x$ and LSMC $x$ composites ( $x=8-37)$ was lower. For the LSCC composites, the difference between the estimated and measured by XPS values was stronger. The modified cerium oxide exists in the LSCC $x$ and LSMC $x$ composites $(x=8-37)$ as a secondary phase and seems to not spread over the surface of the perovskite grains since both [Co or $\mathrm{Mn}]) /[\mathrm{Ce}]$ and $([\mathrm{La}]+[\mathrm{Sr}]+[\mathrm{Co}$ or $\mathrm{Mn}]) /[\mathrm{Ce}]$ atomic ratios were higher than the expected values. The measured and estimated $([\mathrm{La}]+[\mathrm{Sr}]+[\mathrm{Co}$ or $\mathrm{Mn}]) /[\mathrm{Ce}]$ ratios are comparable only for nearly equimolar mixtures (LSCC57 and LSMC57).

Analysis of Ce $3 d$ XPS core level spectra [23] showed that both $\mathrm{Ce}^{4+}$ (high fraction) and $\mathrm{Ce}^{3+}$ cations exist at the surface of grains and interfaces in the systems explored (Figs. 7 and 8). Although the measured surface concentration of Ce cations in the LSCC and LSMC series is comparable (Fig. 8a and b), a much higher fraction of $\mathrm{Ce}^{4+}$ cations seems to exist at the surface of grains in the LSCC series. Due to a low dissolution of Ce cations within the perovskite

Table 3

Lattice parameters of the perovskite phase and cerium oxide in the LSCC and LSMC series.

\begin{tabular}{|c|c|c|c|c|c|}
\hline \multirow[t]{2}{*}{ Composition } & \multicolumn{3}{|l|}{ Perovskite $(R \overline{3} c)$} & \multicolumn{2}{|c|}{ Cerium oxide $(F m \overline{3} m)$} \\
\hline & $\begin{array}{l}\text { Lattice parameters } \\
a[\AA]\end{array}$ & $\beta\left({ }^{\circ}\right)$ & $\begin{array}{l}\text { Cell volume } \\
V[\AA]^{3}\end{array}$ & $\begin{array}{l}\text { Lattice parameter } \\
a[\AA]\end{array}$ & $\begin{array}{l}\text { Cell volume } \\
V[\AA]^{3}\end{array}$ \\
\hline LSC & $5.4048(1)$ & $60.327(1)$ & $112.467(2)$ & - & - \\
\hline LSCC10 & $5.4063(1)$ & $60.380(1)$ & $112.694(2)$ & $5.4982(2)$ & $166.212(18)$ \\
\hline LSCC25 & 5.4096 & $60.398(1)$ & $112.943(2)$ & $5.4675(1)$ & $163.441(5)$ \\
\hline LSCC37 & $5.4143(1)$ & $60.383(1)$ & $113.203(3)$ & $5.4640(1)$ & $163.125(5)$ \\
\hline LSCC57 & $5.4110(1)$ & $60.351(1)$ & $112.916(9)$ & $5.4576(1)$ & $162.557(5)$ \\
\hline LSMC02 & $5.4826(9)$ & $60.549(1)$ & $117.962(3)$ & - & - \\
\hline LSMC10 & $5.4820(7)$ & $60.541(1)$ & 117.920(1) & $5.413(2)$ & $158.6(2)$ \\
\hline LSMC25 & $5.4801(5)$ & $60.540(6)$ & 117.793(17) & $5.4135(6)$ & $158.65(5)$ \\
\hline LSMC57 & $5.4792(5)$ & $60.552(1)$ & $117.764(6)$ & $5.4114(3)$ & $158.47(2)$ \\
\hline $\mathrm{CeO}_{2}$ & - & - & - & $5.4103(9)$ & $158.37(5)$ \\
\hline
\end{tabular}



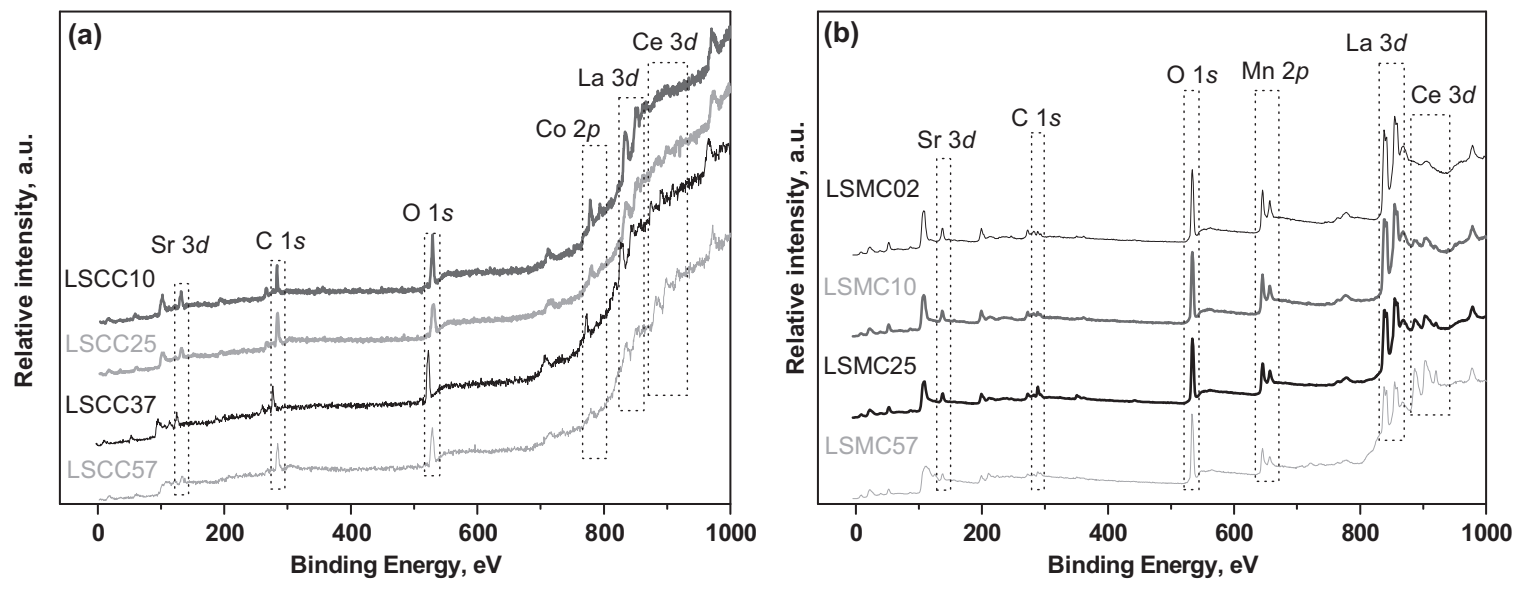

Fig. 4. Survey spectra of compositions in the (a) LSCC and (b) LSMC series.

Table 4

Comparison of the surface concentration of elements (at.\%) derived from XPS and nominal stoichiometry for the LSC and two-phase compositions in the LSCC system.

\begin{tabular}{|c|c|c|c|c|c|c|c|c|c|c|}
\hline \multirow[t]{2}{*}{ Element } & \multicolumn{2}{|l|}{ LSC } & \multicolumn{2}{|c|}{ LSCC10 } & \multicolumn{2}{|c|}{ LSCC25 } & \multicolumn{2}{|c|}{ LSCC37 } & \multicolumn{2}{|c|}{ LSCC57 } \\
\hline & $\mathrm{XPS}^{\mathrm{a}}$ & Nominal & $\mathrm{XPS}^{\mathrm{a}}$ & Nominal & $\mathrm{XPS}^{\mathrm{a}}$ & Nominal & $\mathrm{XPS}^{\mathrm{a}}$ & Nominal & $\mathrm{XPS}^{\mathrm{a}}$ & Nominal \\
\hline La & 10.0 & 12 & 5.0 & 11.3 & 3.5 & 10 & 5.7 & 8.9 & 5.9 & 6.7 \\
\hline $\mathrm{Sr}$ & 11.1 & 8 & 5.2 & 7.5 & 5.6 & 6.7 & 4.7 & 5.9 & 5.6 & 4.5 \\
\hline Co & 6.0 & 20 & 36.4 & 18.7 & 25.8 & 16.7 & 31.7 & 14.8 & 6.1 & 11.1 \\
\hline $\mathrm{Ce}$ & 0 & 0 & 1.3 & 2.1 & 1.6 & 5.6 & 3.1 & 8.7 & 8.2 & 14.8 \\
\hline $\mathrm{O}$ & 72.9 & 60 & 52.1 & 60.4 & 63.5 & 61 & 54.8 & 61.7 & 74.2 & 62.9 \\
\hline
\end{tabular}

a Relative error is $\pm 15 \%$.

Table 5

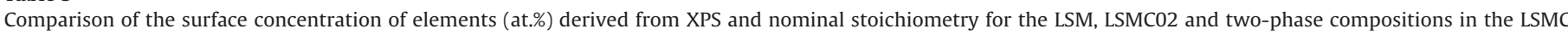
system.

\begin{tabular}{|c|c|c|c|c|c|c|c|c|c|c|}
\hline \multirow[b]{2}{*}{ Element } & \multicolumn{2}{|l|}{ LSM } & \multicolumn{2}{|c|}{ LSMC02 } & \multicolumn{2}{|c|}{ LSMC10 } & \multicolumn{2}{|c|}{ LSMC25 } & \multicolumn{2}{|c|}{ LSMC57 } \\
\hline & $\mathrm{XPS}^{\mathrm{a}}$ & Nominal & $\mathrm{XPS}^{\mathrm{a}}$ & Nominal & $\mathrm{XPS}^{\mathrm{a}}$ & Nominal & $\mathrm{XPS}^{\mathrm{a}}$ & Nominal & $\mathrm{XPS}^{\mathrm{a}}$ & Nominal \\
\hline $\mathrm{La}$ & 12.1 & 16 & 11.6 & 15.8 & 11.0 & 15 & 10.6 & 13.3 & 6.9 & 9.2 \\
\hline $\mathrm{Sr}$ & 5.1 & 4 & 4.7 & 3.9 & 3.9 & 3.8 & 4.0 & 3.3 & 2.7 & 2.3 \\
\hline Mn & 15.0 & 20 & 15.2 & 19.8 & 13.1 & 18.7 & 13.6 & 16.7 & 10.4 & 11.5 \\
\hline $\mathrm{Ce}$ & 0 & 0 & 0 & 0.4 & 0.9 & 2.1 & 2.0 & 5.6 & 6.9 & 14.2 \\
\hline $\mathrm{O}$ & 67.8 & 60 & 68.5 & 60.1 & 71.1 & 60.4 & 69.8 & 61.1 & 73.1 & 62.8 \\
\hline
\end{tabular}

${ }^{a}$ Relative error is $\pm 15 \%$.

structure (about $2 \mathrm{~mol} \%$ ), the changes observed in the Ce $3 d$ spectra are thought to be related to the modified cerium oxide with fluorite structure. Stabilisation of $\mathrm{Ce}^{4+}$ cations in the LSCC series can be explained through the dissolution of Co cations (ionic radius of $\mathrm{Co}^{2+}$ is close to that of $\mathrm{Ce}^{4+}$ cations [47]) within the fluorite structure as it was discussed for the $\mathrm{CeO}_{2}$-based single phase solid solutions (Section 3.1). The surface concentration of $\mathrm{Ce}^{4+}$ cations in the twophase LSMC composites increases with the rise in ceria content,
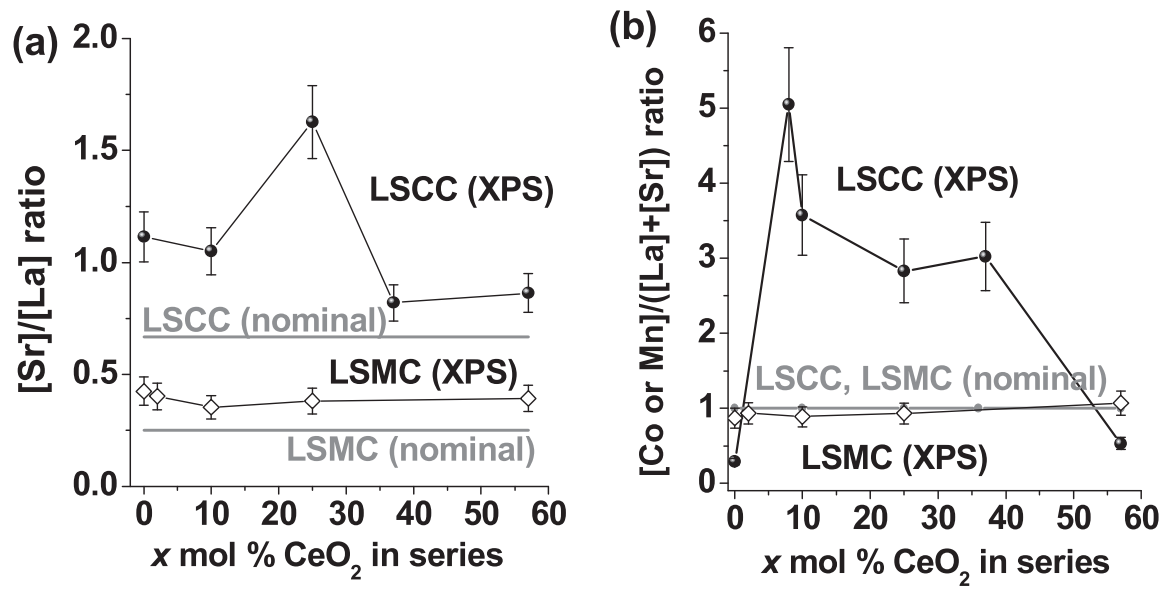

Fig. 5. Atomic ratios of (a) $[\mathrm{Sr}] /[\mathrm{La}]$ and (b) [Co or $\mathrm{Mn}] /([\mathrm{La}]+[\mathrm{Sr}])$ derived from the XPS measurements in comparison with the nominal stoichiometry. 

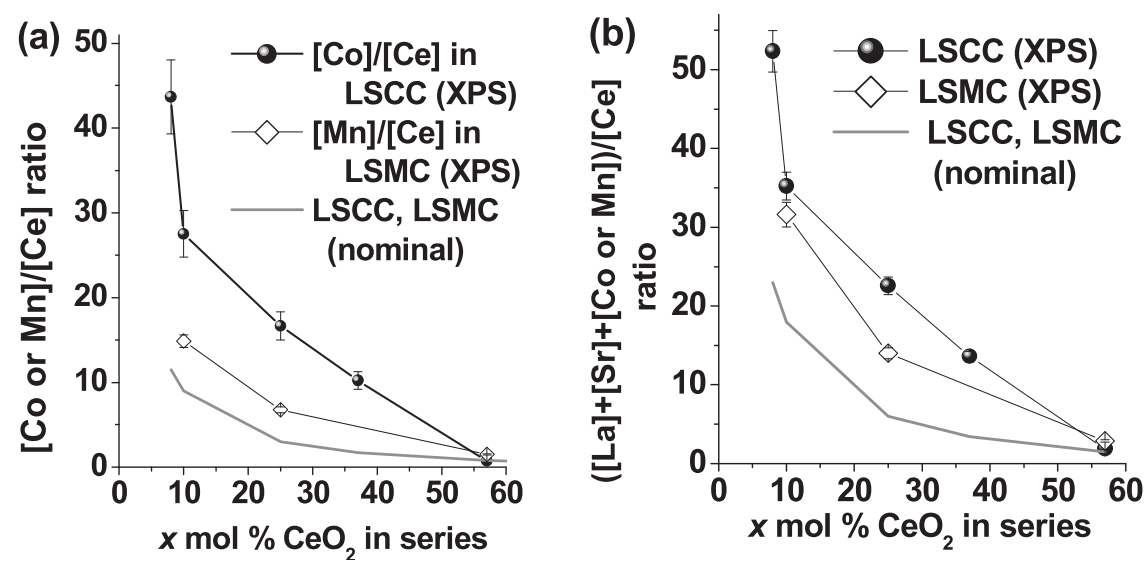

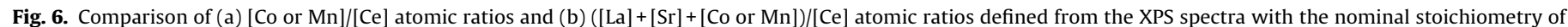
the LSCC and LSMC compositions.

but the $\left[\mathrm{Ce}^{4+}\right] /\left[\mathrm{Ce}^{3+}\right]$ ratio increases only slightly, suggesting the presence of a relatively high fraction of $\mathrm{Ce}^{3+}$ cations $(\sim 26-32 \%)$ across a wide concentration range. In contrast, $\mathrm{Ce}^{4+}$ cations dominate at the surface $(\sim 90-100 \%)$ in the composite oxide system $\mathrm{Ce}_{1-x} \mathrm{Mn}_{x} \mathrm{O}_{2-\delta}$ and $\sim 20-30 \% \mathrm{Ce}^{3+}$ cations at the surface can be attained only for $\mathrm{Au}-\mathrm{Ce}_{1-x} \mathrm{Mn}_{x} \mathrm{O}_{2-\delta}$ composites with a high fraction of cerium cations $(x \leq 0.5)$ [29]. The surface concentration of $\mathrm{Ce}^{4+}$ cations in the two-phase LSCC composites increases also, but the highest $\left[\mathrm{Ce}^{4+}\right] /\left[\mathrm{Ce}^{3+}\right]$ ratio was attained for the LSCC37. About $19 \%$ $\mathrm{Ce}^{3+}$ cations exist at the surface of grains in the LSCC10. This value is lower $(8-12 \%)$ in the LSCC $x(x=25-57)$ composites. A low surface fraction of $\mathrm{Ce}^{3+}$ cations was reported for $(100-x) \mathrm{Co}_{3} \mathrm{O}_{4}-x \mathrm{CeO}_{2}$ composite oxides with a high fraction of cerium oxide $(x \geq 50 \mathrm{~mol} \%)$ [30]. (a)

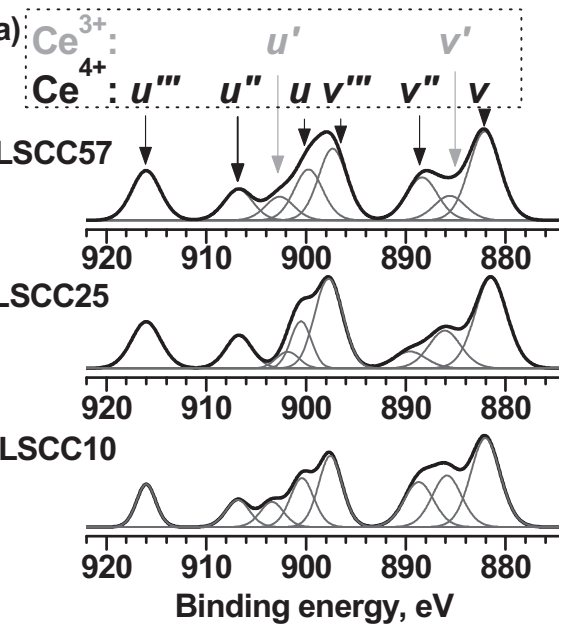

(b)
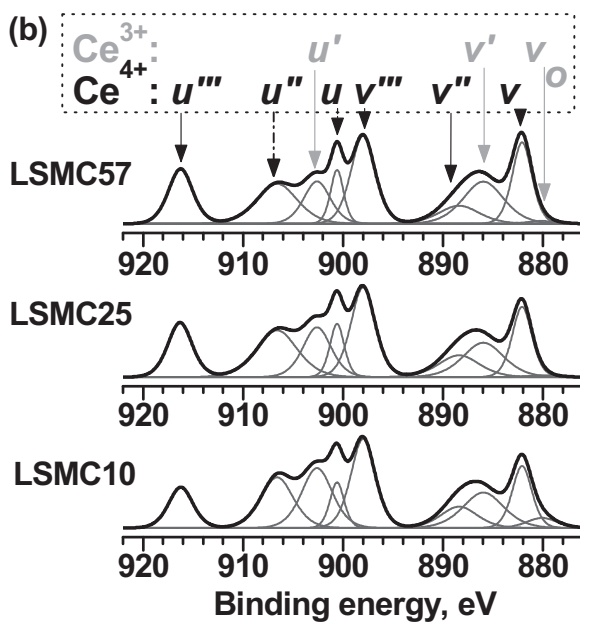

Fig. 7. Curve-fitted Ce $3 d$ core level spectra measured for the two phase (a) LSCC and (b) LSMC compositions.
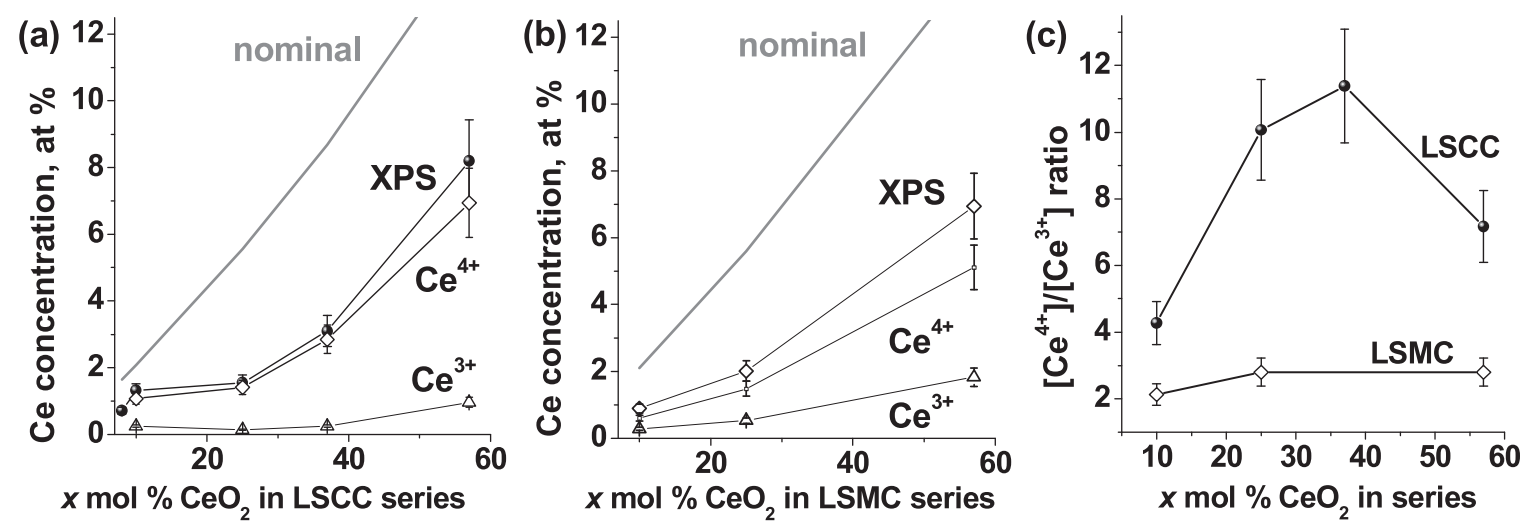

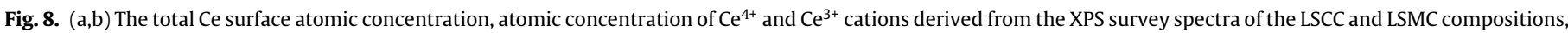
respectively, in comparison with the stoichiometry; and (c) $\left[\mathrm{Ce}^{4+}\right] /\left[\mathrm{Ce}^{3+}\right]$ atomic ratios in the LSCC and LSMC series defined from the Ce $3 d$ core level spectra. 
(a) LSCC system

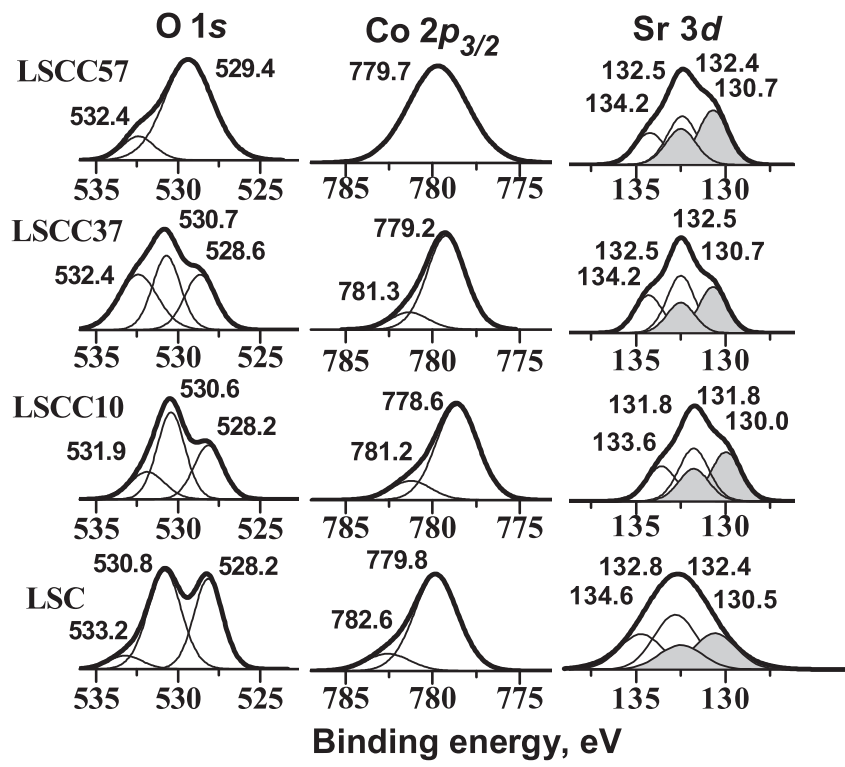

(b) LSMC system

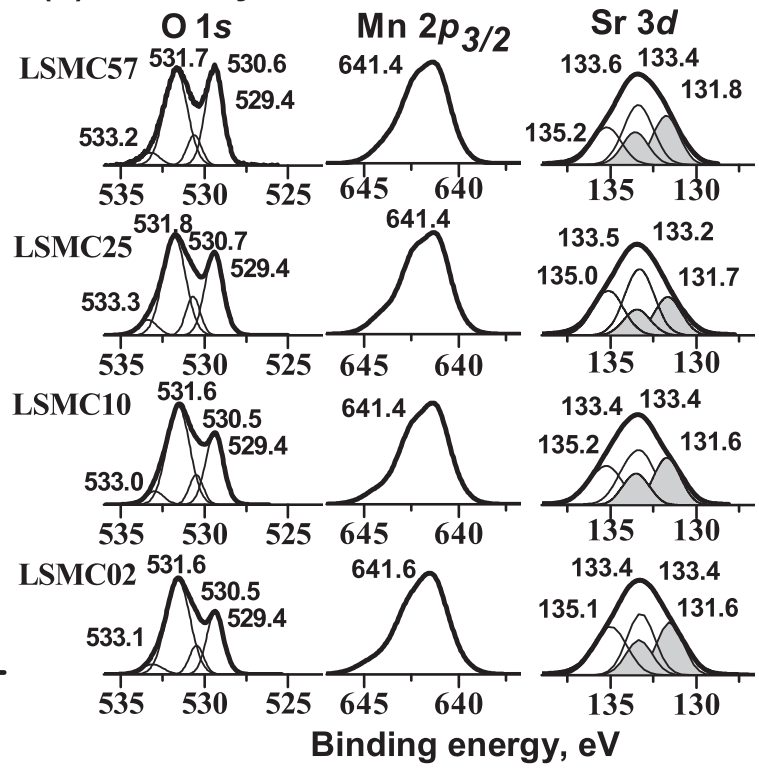

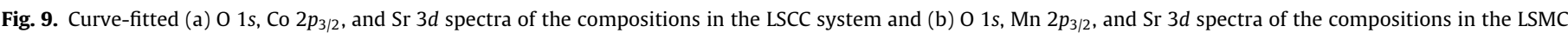
system.

\subsection{Surface states of Co and Sr cations, carbon, and oxygen ions in the LSCC composites}

The Co $2 p_{3 / 2}$ core level spectrum of the LSC is asymmetric and can be situated at $779.8 \mathrm{eV}$ (Fig. 9a), representing $\mathrm{Co}^{3+}$ cations $[55,62]$. One could extract a small shoulder on the high binding energy side of the Co $2 p_{3 / 2}$ spectrum. A comparison of the XPS spectra (including shake-up features) reported in the literature for $\mathrm{La}_{1-x} \mathrm{Sr}_{x} \mathrm{CoO}_{3 \pm \delta}, \mathrm{SrCo}^{4+} \mathrm{O}_{3}$, Co oxides and hydroxides [36,39,62-66] implies that a small peak at $782.6 \mathrm{eV}$ could be related to the presence of $\mathrm{Co}^{4+}$ cations. This correlates with the result of the thermal gravimetric analysis showing the average oxidation state of Co cations in the LSC as +3.4 [39]. The Co $2 p_{3 / 2}$ spectra of the LSCC10 and LSCC37 have the same shape as for LSC, but a shift towards low binding energy was observed, indicating the presence of a certain fraction of $\mathrm{Co}^{2+}$ cations at the surface. Notice that the Co $2 p_{3 / 2}$ peak in $\mathrm{LaCoO}_{3}$ reduced in $\mathrm{H}_{2}$ at $450{ }^{\circ} \mathrm{C}$ is centred at $778.0 \mathrm{eV}$ [66]. The presence of $\mathrm{Co}^{2+}$ cations at the surface may be interrelated with the dissolution of Co cations into the fluorite structure of the modified cerium oxide. However, the Co $2 p_{3 / 2}$ spectra of the LSCC57 are broader compared to the LSC (Fig. 9a), indicating the involvement of Co cations in a local disorder taking place at or near the surface region.

The $\mathrm{O} 1 s$ spectra recorded for the LSC and LSCC $x$ composites are complex and contain several contributions that vary with an increasing in cerium oxide content (Fig. 9a). The $01 s$ components at a lower binding energy $B E \sim 528.2 \mathrm{eV}$ (LSC and LSCC10) and $528.6 \mathrm{eV}$ (LSCC37) can be assigned to the lattice oxygen [36,55,64]. It could be interpreted as similar mobilities of the lattice oxygen in the LSC and LSCC10, indicating an absence of obstructions for oxygen transport in the area directly adjacent to the phase interfaces and across the interface modified perovskite/modified ceria\}. In the LSCC57, the $O 1 s$ components at $B E \sim 528.2-528.6 \mathrm{eV}$ was not revealed, but the peak at $B E \sim 529.4 \mathrm{eV}$ was observed and can be assigned to the lattice oxygen in pure or doped $\mathrm{CeO}_{2}[24,55]$ and to $\mathrm{SrO}$ species on the surface of perovskites [36]. The O $1 \mathrm{~s}$ component at $\sim 530.6-530.8 \mathrm{eV}$ (LSC, LSCC10, and LSCC37) could be associated with O-Co surface species in perovskites [36] and this component is strong for the LSC, LSCC10, and LSCC37 compositions. The $01 s$ components at higher binding energies are slightly different for the LSCC $x(x=10-57)$ composites and LSC. The O $1 s$ component at $533.2 \mathrm{eV}$ in the LSC could be ascribed to the chemisorbed dioxygen species $(B E \sim 532.7-533.5 \mathrm{eV})$, whereas those at $531.9-532.4 \mathrm{eV}$ in the LSCC $x(x=10-57)$ could be related to O-Ce surface species.

The Sr $3 d$ spectra recorded for the LSC and LSCC $x(x=10-57)$ composites contain the two spin-orbit components $3 d_{5 / 2}$ and $3 d_{3 / 2}$ (Fig. 9a). The two contributions (at lower and higher binding energies) can be distinguished. The contributions at lower binding energies (130.0-130.7 eV for $3 d_{5 / 2}$ and $131.8-132.5 \mathrm{eV}$ for $\left.3 d_{3 / 2}\right)$ is difficult to assign as it is in general is lower by about $1 \mathrm{eV}$ compared to the values usually reported for the Sr cations in the perovskite lattice $\left(\mathrm{Sr}_{\text {latt }}\right)$ [36]. A peak at a low binding energy of $130.5 \mathrm{eV}$ was reported in [67], but authors were not able to identify the origin of this peak. The features observed at higher binding energy in the LSCC10 ( $131.8 \mathrm{eV}$ for $3 d_{5 / 2}$ and $133.6 \mathrm{eV}$ for $3 d_{3 / 2}$ ) could be attributed to the $\mathrm{Sr}$ cations in the perovskite lattice $\left(\mathrm{Sr}_{\text {latt }}\right)$ [36]. In the LSC, LSCC37, and LSCC57, the second doublet is located at higher binding energies (132.4-132.8 eV for $3 d_{5 / 2}$ and $134.2-134.6 \mathrm{eV}$ for $3 d_{3 / 2}$ ) than for the LSCC10 and could be attributed to the Sr surface states $\left(\mathrm{Sr}_{\text {surf }}\right)$. To identify the origin of the $\mathrm{Sr}_{\text {surf }}$ we compare the $B E$ of $\mathrm{Sr} 3 d, \mathrm{O} 1 s$, and C $1 s$ features. The values of the $\mathrm{Sr} 3 d, \mathrm{O} 1 s$, and $\mathrm{C} 1 \mathrm{~s}$ binding energies (in $\mathrm{eV}$ ) reported in the literature for different $\mathrm{Sr}, \mathrm{O}$, and $\mathrm{C}$ containing compounds are summarised in Table 6 $[36,57,58,68,69]$. The feature at $288.5 \mathrm{eV}$ was clearly observed in the C $1 s$ spectra of the LSC perovskite and LSCC57 composite, thereby implying the possibility of carbonate formation. Notice, that $\mathrm{Sr} 3 p$ spectra ( $B E \sim 268-269 \mathrm{eV}$ for $\mathrm{Sr} 3 p_{3 / 2}$ and $B E \sim 278-279 \mathrm{eV} \mathrm{Sr} 3 p_{1 / 2}$ [70]) are very close to the $C 1 s$ region, making an apparent impression on the existence of several peaks in the $C 1 s$ spectra. The $\mathrm{Sr}_{\text {surf }}$ features revealed for the LSC $\left(B E=132.8 \mathrm{eV}\right.$ for $3 d_{5 / 2}$ and $134.6 \mathrm{eV}$ for $3 d_{3 / 2}$ ) could be assigned to $\mathrm{Sr}(\mathrm{OH})_{2}$ [68], $\mathrm{SrCO}_{3}$ [58], and $\mathrm{SrO}_{2}$ [68] (Table 6). The $01 \mathrm{~s}$ spectrum of the LSC is complex and the feature at $530.8 \mathrm{eV}$ is strong (Fig. 9a and Table 6), suggesting the coexistence of all three phases: $\mathrm{Sr}(\mathrm{OH})_{2}$ [68], $\mathrm{SrCO}_{3}$ [58], and $\mathrm{SrO}_{2}$ [68]. It seems that SrO surface phase could form in the LSCC37 and LSCC57 composites $\left(B E=132.4-132.5 \mathrm{eV}\right.$ for $3 d_{5 / 2}$ and $134.2 \mathrm{eV}$ for $3 d_{3 / 2}$ ). Although the feature at $528.2 \mathrm{eV}$ is not dominant in the $\mathrm{O}$ 1s spectra of the LSCC37 and LSCC57 composites (Fig. 9a), one can 
Table 6

Comparison of the $\mathrm{Sr} 3 d, \mathrm{O} 1 \mathrm{~s}$, and C $1 \mathrm{~s}$ binding energies (in eV) reported in the literature for different $\mathrm{Sr}$ and $\mathrm{O}$ containing compounds.

\begin{tabular}{|c|c|c|c|c|c|}
\hline \multirow[t]{3}{*}{ Phase } & \multicolumn{4}{|c|}{ Binding energy, eV } & \multirow[t]{3}{*}{ Ref. } \\
\hline & \multicolumn{2}{|c|}{ Sr $3 d$} & \multirow[t]{2}{*}{$01 s$} & \multirow[t]{2}{*}{$\mathrm{C} 1 \mathrm{~s}$} & \\
\hline & $3 d_{5 / 2}$ & $3 d_{3 / 2}$ & & & \\
\hline $\mathrm{Sr}(\mathrm{OH})_{2}$ & 132.8 & 134.5 & 530.5 & - & [68] \\
\hline $\mathrm{SrCO}_{3}$ & 132.7 & - & 530.9 & $288.8 \mathrm{eV}$ & [58] \\
\hline $\mathrm{SrCO}_{3}$ (on the surface of perovskites) & 134.0 & - & 532.0 & 288.5 & [36] \\
\hline $\mathrm{SrO}$ (on the surface of perovskites) & 133.0 & - & 529.8 & - & [36] \\
\hline $\mathrm{SrO}_{2}$ & 132.7 & 134.6 & $531.1 \mathrm{eV}$ & - & [68] \\
\hline $\mathrm{SrO}$ & 132.4 & 134.0 & $528.2 \mathrm{eV}$ & - & [69] \\
\hline $\mathrm{Ce}_{2}\left(\mathrm{CO}_{3}\right)_{3} \cdot 8 \mathrm{H}_{2} \mathrm{O}$ & - & - & 531 & $288.7 \mathrm{eV}$ & [57] \\
\hline
\end{tabular}

distinguish its contribution through the formal fitting procedure. For the LSCC57, in addition, one may assume the existence of $\mathrm{SrCO}_{3}$ [58] due to the feature at $288.5 \mathrm{eV}$ in the $\mathrm{C} 1 \mathrm{~s}$ spectrum although there is some difference in the $\mathrm{Sr} 3 d_{5 / 2}$ position $(\Delta=0.3 \mathrm{eV})$. The formation of $\mathrm{Ce}_{2}\left(\mathrm{CO}_{3}\right)_{3}$-based phase [57] at the surface of grains in the LSCC57 should be also taken into consideration (Table 6).

\subsection{Surface states of Mn and Sr cations, carbon, and oxygen ions in the LSMC composites}

The Mn $2 p_{3 / 2}$ and $01 s$ spectra measured for the LSMC compositions are presented on Fig. $9 \mathrm{~b}$. The Mn $2 p$ XPS spectra cannot be easily analysed through a simple fitting procedure concerning the contribution of $\mathrm{Mn}^{2+}, \mathrm{Mn}^{3+}$, and $\mathrm{Mn}^{4+}$ compounds because of the multiple splitting of the Mn $2 p$ spectra of individual $\mathrm{Mn}^{2+}, \mathrm{Mn}^{3+}$, and $\mathrm{Mn}^{4+}$ cations [71,72]. However, we compared the measured XPS spectra for the LSMCO2 and LSMC $x(x=10-57)$ composites with the XPS spectra for $\mathrm{LaMn}^{3+} \mathrm{O}_{3}$ with oxidation state defined from the neutron diffraction and studies of the magnetic properties [62]. The $\mathrm{Mn} 2 p_{3 / 2}$ peak of $\mathrm{LaMn}^{3+} \mathrm{O}_{3}$ can be centred at $640.4 \mathrm{eV}$, implying the presence of both $\mathrm{Mn}^{3+}$ and $\mathrm{Mn}^{4+}$ cations in the LSMCO2 and LSMCX $(x=10-57)$ composites. In the LSMC $x(x=10-57)$, the Mn $2 p_{3 / 2}$ spectra have the same shape as for the LSMC02 although a very slight $\operatorname{shift}(\sim 0.2 \mathrm{eV})$ to a lower banding energy was observed in their core level spectra, suggesting a slight decrease in the fraction of $\mathrm{Mn}^{4+}$ cations on the B-sites within the perovskite structure.

The 0 1s spectra measured for the LSMC02 and LSMC $x$ $(x=10-57)$ composites also have several components. The existence of the feature at $529.4 \mathrm{eV}$ in the $\mathrm{O} 1 \mathrm{~s}$ spectra and its increase on the rise in $\mathrm{CeO}_{2}$ content (Fig. 9b) implies that it could be assigned to both lattice oxygen in Mn containing perovskite phase [73] and lattice oxygen in $\mathrm{CeO}_{2}$ or mixed oxides [23,55]. A higher value of $B E$ for the lattice oxygen in the LSMC series compared to those in the LSCC series is reasonable as the LSM has lower ionic conductivity than the LSC $[74,75]$. The $\mathrm{O} 1 \mathrm{~s}$ features at $530.5-530.7 \mathrm{eV}$ may be associated with O-Mn surface species in perovskites. Notice that this component is much less for the LSMC composites than for the LSC and LSCC $x(x=10-37)$ compositions that correlates with a higher value of oxygen surface exchange coefficient in $\mathrm{La}_{0.5} \mathrm{Sr}_{0.5} \mathrm{CoO}_{3}$ (by $\sim 4$ orders of magnitude at $\sim 750{ }^{\circ} \mathrm{C}$ ) compared to $\mathrm{La}_{0.5} \mathrm{Sr}_{0.5} \mathrm{MnO}_{3}$ [76]. The features at $\sim 531.6-531.8 \mathrm{eV}$ and $533.0-533.3 \mathrm{eV}$, respectively, could be attributed to the O-Ce surface species and the chemisorbed dioxygen species [36].

The $\mathrm{Sr} 3 d$ spectra recorded for the LSMC02 and LSMC $x$ $(x=10-57)$ composites contain the two spin-orbit components $3 d_{5 / 2}$ and $3 d_{3 / 2}$ (Fig. 9b). The two contributions (at lower and higher binding energies) can be distinguished. The contributions at lower binding energies (131.6-131.8 eV for $3 d_{5 / 2}$ and 133.4-133.6 eV for $3 d_{3 / 2}$ ) are close to the $\mathrm{Sr} 3 d$ features reported for $\mathrm{La}_{0.8-x} \mathrm{Ce}_{x} \mathrm{Sr}_{0.2} \mathrm{MnO}_{3}$ [77] and could be assigned to the $\mathrm{Sr}$ cations in the perovskite lattice $\left(\mathrm{Sr}_{\text {latt }}\right)$. The features observed at higher binding energies (133.2-133.4 $\mathrm{eV}$ for $3 d_{5 / 2}$ and $135.0-135.2 \mathrm{eV}$ for $\left.3 d_{3 / 2}\right)$ can be attributed to the Sr surface states $\left(\mathrm{Sr}_{\text {surf }}\right)$. To identify the origin of the $\mathrm{Sr}_{\text {surf }}$ we also compare the $B E$ of features in the $\mathrm{Sr} 3 d, \mathrm{O} 1 \mathrm{~s}$, and $\mathrm{C} 1 \mathrm{~s}$ spectra obtained in the present study with those reported in the literature for different $\mathrm{Sr}, \mathrm{O}$, and $\mathrm{C}$ containing compounds (Table 6). The BE values of the $\mathrm{Sr}_{\text {surf }}$ in the LSMC02 and LSMC $x(x=10-57)$ composites differ from those reported for $\mathrm{SrCO}_{3}$ as individual phase [58] and for $\mathrm{SrCO}_{3}$ states on the surface of perovskites [36] (Table 6). The $B E$ values of the $\mathrm{Sr}_{\text {surf }}$ in the LSMC $x$ $(x=2-57)$ are closer to that reported for the SrO states on the surface of perovskites [36]. Their existence could be confirmed by the feature at $529.8 \mathrm{eV}$ in the $\mathrm{O} 1 \mathrm{~s}$ spectra [36] of the LSMC compositions. In fact, a strong feature was observed at $529.4 \mathrm{eV}$ in the $\mathrm{O} 1 \mathrm{~s}$ spectra of the LSMC $x(x=2-57)$ (Fig. 9b) and was assigned to both lattice oxygen in perovskite phase [73] and lattice oxygen in $\mathrm{CeO}_{2}$ or mixed oxides [23,55]. The feature at $529.8 \mathrm{eV}$ is not obvious spectroscopically, but its contribution could be distinguished through the formal curve-fitting solution, suggesting the existence of strontium in the form of the SrO species on the surface of perovskite phase.

The $C 1 s$ spectra of the LSMC02 and LSMC $x(x=10-57)$ composites contain the two components at $284.6 \mathrm{eV}$ and at $288.6-289.0 \mathrm{eV}$. The least component may be related in general to several carbon containing phases (Table 6): $\mathrm{Ce}_{2}\left(\mathrm{CO}_{3}\right)_{3} \cdot 8 \mathrm{H}_{2} \mathrm{O}$ (C $1 \mathrm{~s} \mathrm{BE}=288.7 \mathrm{eV}$ [57]) and $\mathrm{SrCO}_{3}$ (C $1 \mathrm{~s} \quad B E=288.8 \mathrm{eV}$ [58]). Strong features at $132.7 \mathrm{eV}$ or $134 \mathrm{eV}$ in the $\mathrm{Sr} 3 d_{5 / 2}$ spectra of the LSMC $x(x=2-57)$ was not observed. Therefore, one may assume the existence of $\mathrm{Ce}_{2}\left(\mathrm{CO}_{3}\right)_{3}$-based phase at the surface of grains and crystallites in the LSCM02 and LSMCX $(x=10-57)$ composites. In this case, the feature at $531.0 \mathrm{eV}$ should be observed in the $01 \mathrm{~s}$ spectra of the LSMC $x(x=2-57)$ compositions [57]. The very strong features at $\sim 531.6-531.8 \mathrm{eV}$ were initially attributed to the O-Ce surface species, but the contributions at $531.0-531.4 \mathrm{eV}$ could be distinguished through the formal fitting procedure and support the above mentioned assumption.

\section{Conclusions}

The surface composition and chemical states of ions were studied in the single phase $\mathrm{CeO}_{2}$-based solid solutions, in the $\mathrm{La}_{0.6} \mathrm{Sr}_{0.4} \mathrm{CoO}_{3}-\mathrm{CeO}_{2}$ (LSCC) and $\mathrm{La}_{0.8} \mathrm{Sr}_{0.2} \mathrm{MnO}_{3}-\mathrm{CeO}_{2}$ (LSMC) composite systems. The composite systems were prepared through reactive sintering at $1350^{\circ} \mathrm{C}$ under air. The surface segregation of $\mathrm{Sr}$ was revealed for the $\mathrm{Ce}_{0.905} \mathrm{La}_{0.028} \mathrm{Sr}_{0.019} \mathrm{Co}_{0.048} \mathrm{O}_{2-\delta}$ and $\mathrm{Ce}_{0.808} \mathrm{La}_{0.058} \mathrm{Sr}_{0.038} \mathrm{Co}_{0.096} \mathrm{O}_{2-\delta}$ single phase solid solutions with fluorite structure, $\mathrm{La}_{0.6} \mathrm{Sr}_{0.4} \mathrm{CoO}_{3}$ and LSMC02 perovskites, LSCC57 and LSMC $x(x=10-57)$ composites consisting of the phases with perovskite and fluorite structures. La and Co cations were not found on the surface in the single phase solid solutions, suggesting the complete dissolution of these cations into the fluorite structure. The surface strontium seems to exist in the form of SrO on the surface of the perovskite phase in the LSMC $x(x=10-57)$ composites. In the LSCC system, the surface state of $\mathrm{Sr}$ is more diverse. 
$\mathrm{Sr}(\mathrm{OH})_{2}, \mathrm{SrCO}_{3}$, and $\mathrm{SrO}_{2}$ phases could coexist at the surface in $\mathrm{La}_{0.6} \mathrm{Sr}_{0.4} \mathrm{CoO}_{3}$ perovskite. SrO surface phase seems to dominate in the $\mathrm{LSCC} 37$ composite. In addition to $\mathrm{SrO}, \mathrm{SrCO}_{3}$ may form at the surface in the LSCC57 composite. The surfaces of grains and interfaces in the LSCC and LSMC systems are depleted in cerium although both $\mathrm{Ce}^{4+}$ and $\mathrm{Ce}^{3+}$ cations were revealed. The surface fraction of $\mathrm{Ce}^{4+}$ cations is higher by about a factor of two in the two phase LSCC compositions that could be explained through the dissolution of $\mathrm{Co}$ cations into the fluorite structure. The Mn surface concentration in the $\operatorname{LSMC} x(x=2-37 \mathrm{~mol} \%)$ compositions is slightly less compared to the nominal stoichiometry. Both $\mathrm{Mn}^{4+}$ and $\mathrm{Mn}^{3+}$ cations are present at the surface in the LSMC02 and their ratio remains nearly the same across a wide concentration range $(x=10-57 \mathrm{~mol} \%)$. In the LSCC $x$ ( $x=8-40 \mathrm{~mol} \%)$, however, the presence of modified cerium oxide as a secondary phase results in a strong enrichment of the surface by Co cations. The O $1 \mathrm{~s}$ spectra recorded for the LSCC and LSMC compositions are complex and contain several contributions. In contrast to the LSMC series, much stronger evolution of the $\mathrm{O} 1 \mathrm{~s}$ XPS spectra was revealed in the LSCC series, reflecting the variation in origin of the oxygen species involved in the surface processes. The $\mathrm{Ce}_{2}\left(\mathrm{CO}_{3}\right)_{3}$-based phase exists at the surface of grains and crystallites in the LSCM02, LSMC $x(x=10-57)$ and LSCC57 composites.

\section{Acknowledgment}

The authors gratefully acknowledge Prof.J.T.S. Irvine for his kind support.

\section{References}

1] R.J.H. Voorhoeve, J.P. Remeika, P.E. Freeland, B.T. Matthias, Rare-earth oxides of manganese and cobalt rival platinum for the treatment of carbon monoxide in auto exhaust, Science 177 (1972) 353-354.

[2] J.O. Petunchi, J.L. Nicastro, E.A. Lombardo, Ethylene hydrogenation over $\mathrm{LaCoO}_{3}$ perovskite, Journal of the Chemical Society, Chemical Communications (1980) 467-468.

[3] A. Trovarelli, Catalytic properties of ceria and $\mathrm{CeO}_{2}$-containing materials, Catalysis Reviews Science and Engineering 38 (1996) 439-520.

[4] D. Ferri, NO reduction by $\mathrm{H}_{2}$ over perovskite-like mixed oxides, Applied Catalysis B: Environmental 16 (1998) 339-345.

[5] E.A. Lombardo, M.A. Ulla, Perovskite oxides in catalysis: past, present and future, Research on Chemical Intermediates 24 (1998) 581-592.

[6] A. Sin, E. Kopnin, Y. Dubitsky, A. Zaopo, A.S. Aricò, L.R. Gullo, D.La Rosa, V. Antonucci, Stabilisation of composite LSFCO-CGO based anodes for methane oxidation in solid oxide fuel cells, Journal of Power Sources 145 (2005) 68-73.

[7] D.G. Cheng, M. Chong, F. Chen, X. Zhan, XPS characterization of $\mathrm{CeO}_{2}$ catalyst for hydrogenation of benzoic acid to benzaldehyde, Catalysis Letters 120 (2008) 82-85.

[8] M. Mogensen, T. Lindegaard, U.R. Hansen, G. Mogensen, Physical properties of mixed conductor solid oxide fuel cell anodes of doped $\mathrm{CeO}_{2}$, Journal of the Electrochemical Society 141 (1994) 2122-2128.

[9] N.T. Hart, N.P. Brandon, M.J. Daya, N. Lapena-Rey, Functionally graded composite cathodes for solid oxide fuel cells, Journal of Power Sources 106 (2002) 42-50.

[10] X. Zhu, Z. Lü, B. Wei, K. Chen, M. Liu, X. Huang, W. Su, Enhanced performance of solid oxide fuel cells with $\mathrm{Ni} / \mathrm{CeO}_{2}$ modified $\mathrm{La}_{0.75} \mathrm{Sr}_{0.25} \mathrm{Cr}_{0.5} \mathrm{Mn}_{0.5} \mathrm{O}_{3-\delta}$ anodes, Journal of Power Sources 190 (2009) 326-330.

[11] E. Konysheva, A.D. Bonaccorso, J.T.S. Irvine, Electrochemical characteristics of cathodes based on perovskites modified by ceria, Russian Journal of Electrochemistry 46 (2010) 805-810.

[12] E. Antolini, J. Perez, The use of rare earth-based materials in low-temperature fuel cells, International Journal of Hydrogen Energy 36 (2011) 1575215765.

[13] P. Fornasiero, J. Kašpar, M. Graziani, On the rate determining step in the reduction of $\mathrm{CeO}_{2}-\mathrm{ZrO}_{2}$ mixed oxides, Applied Catalysis B: Environmental 22 (1999) L11-L14.

[14] T.X.T. Sayle, S.C. Parker, C.R.A. Catlow, Surface oxygen vacancy formation on $\mathrm{CeO} 2$ and its role in the oxidation of carbon monoxide, Journal of the Chemical Society, Chemical Communications (1992) 977-978.

[15] Z. Yang, X. Yu, Z. Lu, S. Li, K. Hermansson, Oxygen vacancy pairs on $\mathrm{CeO}_{2}(110)$ : a DFT + U study, Physics Letters A 373 (2009) 2786-2792.

[16] J. Li, Y. Han, Y. Zhu, R. Zhou, Purification of hydrogen from carbon monoxide for fuel cell application over modified mesoporous $\mathrm{CuO}-\mathrm{CeO}_{2}$ catalysts, Applied Catalysis B: Environmental 108/109 (2011) 72-80.

[17] G. Ertl, J. Küppers, Low Energy Electrons and Surface Chemistry, 2nd ed., VCH Publisher, Weinheim, Federal Republic of Germany, 1985, p. 374.
[18] P. Burroughs, A. Hamnett, A.F. Orchard, G. Thornton, Satellite structure in the $\mathrm{X}$-ray photoelectron spectra of some binary and mixed oxides of lanthanum and cerium, Journal of the Chemical Society, Dalton Transactions 17 (1976) 1686-1698.

[19] T.L. Barr, An ESCA study of termination of the passivation of elemental metal, Journal of Physical Chemistry 82 (1978) 1801-1810.

[20] A.Pfau, K.D. Schierbaum, The electronic structure of stoichiometric and reduced $\mathrm{CeO}_{2}$ surfaces: an XPS, UPS and HREELS study, Surface Science 321 (1994) 71-80.

[21] M. Alexandrou, R.M. Nix, The growth, structure and stability of ceria overlayers on Pd(111), Surface Science 321 (1994) 47-57.

[22] A. Kotani, T. Jo, J.C. Parlebas, Many-body effects in core-level spectroscopy of rare-earth compounds, Advanced Physics 37 (1988) 37-85.

[23] F. Zhang, P. Wang, J. Koberstein, S. Khalid, S.W. Chan, Cerium oxidation state in ceria nanoparticles studied with X-ray photoelectron spectroscopy and absorption near edge spectroscopy, Surface Science 563 (2004) 74-82.

[24] A. Galtayries, R. Sporken, J. Riga, G. Blanchard, R. Caudano, XPS comparative study of ceria/zirconia mixed oxides: powders and thin film characterization, Journal of Electron Spectroscopy and Related Phenomena 88/91 (1998) 951-956.

[25] N. Wang, W. Chu, T. Zhang, X.S. Zhao, Manganese promoting effects on the $\mathrm{Co}-\mathrm{Ce}-\mathrm{Zr}-\mathrm{O}_{x}$ nano catalysts for methane dry reforming with carbon dioxide to hydrogen and carbon monoxide, Chemical Engineering Journal 170 (2011) 457-463.

[26] E. Bêche, P. Charvin, D. Perarnau, S. Abanades, G. Flamant, Ce 3d XPS investigation of cerium oxides and mixed cerium oxide $\left(\mathrm{Ce}_{x} \mathrm{Ti}_{y} \mathrm{O}_{z}\right)$, Surface and Interface Analysis 40 (2008) 264-267.

[27] M. Romeo, K. Bak, J. El Fallah, F. Le Normand, L. Hilaire, XPS Study of the reduction of cerium dioxide, Surface and Interface Analysis 20 (1993) 508-512.

[28] H. Cordatos, R.J. Gorte, $\mathrm{CO}_{2}, \mathrm{NO}_{2}$, and $\mathrm{H}_{2}$ adsorption on ceria-supported Pd, Journal of Catalysis 159 (1996) 112-118.

[29] F. Larachi, J. Pierre, A. Adnot, A. Bernis, Ce 3d XPS study of composite $\mathrm{Ce}_{x} \mathrm{Mn}_{1-x} \mathrm{O}_{2-y}$ wet oxidation catalysts, Applied Surface Science 195 (2002) 236-250.

[30] L.F. Liotta, G. Di Carlo, G. Pantaleo, A.M. Venezia, G. Deganello, $\mathrm{Co}_{3} \mathrm{O}_{4} / \mathrm{CeO}_{2}$ composite oxides for methane emissions abatement: relationship between $\mathrm{CO}_{3} \mathrm{O}_{4}-\mathrm{CeO}_{2}$ interaction and catalytic activity, Applied Catalysis B: Environmental 66 (2006) 217-227.

[31] J. Fan, X. Wu, X. Wu, Q. Liang, R. Ran, D. Weng, Thermal ageing of Pt on lowsurface-area $\mathrm{CeO}_{2}-\mathrm{ZrO}_{2}-\mathrm{La}_{2} \mathrm{O}_{3}$ mixed oxides: effect on the OSC performance, Applied Catalysis B: Environmental 81 (2008) 38-48.

[32] K.H. Kim, J.R. Kim, S.K. Ihm, Wet oxidation of phenol over transition metal oxide catalysts supported on $\mathrm{Ce}_{0.65} \mathrm{Zr}_{0.35} \mathrm{O}_{2}$ prepared by continuous hydrothermal synthesis in supercritical water, Journal of Hazardous Materials 167 (2009) 1158-1162.

[33] S.S.Y. Lin, D.H. Kim, M.H. Engelhard, S.Y. Ha, Water-induced formation of cobalt oxides over supported cobalt/ceria-zirconia catalysts under ethanol-steam conditions, Journal of Catalysis 273 (2010) 229-235.

[34] W.J. Hong, S. Iwamoto, S. Hosokawa, K. Wada, H. Kanai, M. Inoue, Effect of Mn content on physical properties of $\mathrm{CeO}_{x}-\mathrm{MnO}_{y}$ support and $\mathrm{BaO}_{x}-\mathrm{CeO}_{y}-\mathrm{MnO}_{z}$ catalysts for direct NO decomposition, Journal of Catalysis 277 (2011) 208-216.

[35] Y.M. Choi, M.C. Lin, M. Liu, Computational study on the catalytic mechanism of oxygen reduction on $\mathrm{La}_{0.5} \mathrm{Sr}_{0.5} \mathrm{MnO}_{3}$ in solid oxide fuel cells, Angewandte Chemie 119 (2007) 7352-7357.

[36] P.A.W. van der Heide, Systematic X-ray photoelectron spectroscopic study of $\mathrm{La}_{1-x} \mathrm{Sr}_{x}$-based perovskite-type oxides, Surface and Interface Analysis 33 (2002) 414-425

[37] N. Caillol, M. Pijolat, E. Siebert, Investigation of chemisorbed oxygen, surface segregation and effect of post-treatments on $\mathrm{La}_{0.8} \mathrm{Sr}_{0.2} \mathrm{MnO}_{3}$ powder and screen-printed layers for solid oxide fuel cell cathodes, Applied Surface Science 253 (2007) 4641-4648.

[38] G.J. la O', R.F. Savinell, Y. Shao-Horna, Activity enhancement of dense strontium-doped lanthanum manganite thin films under cathodic polarization: a combined AES and XPS Study, Journal of the Electrochemical Society 156 (2009) B771-B781.

[39] E. Konysheva, S.M. Francis, J.T.S. Irvine, Crystal structure oxygen nonstoichiometry, and conductivity of mixed ionic-electronic conducting perovskite composites with $\mathrm{CeO}_{2}$, Journal of the Electrochemical Society 157 (2010) B159-B165.

[40] J.H. Joo, R. Merkle, J. Maier, Effects of water on oxygen surface exchange and degradation of mixed conducting perovskites, Journal of Power Sources 196 (2011) 7495-7499.

[41] E. Bucher, W. Sitte, Long-term stability of the oxygen exchange properties of $(\mathrm{La}, \mathrm{Sr})_{1-z}(\mathrm{Co}, \mathrm{Fe}) \mathrm{O}_{3-\delta}$ in dry and wet atmospheres, Solid State Ionics 192 (2011) $480-482$.

[42] H.M. Rietveld, A profile refinement method for nuclear and magnetic structures Journal of Applied Crystallography 2 (1969) 65-71.

[43] A.C. Larson, R.B. von Dreele, GSAS - Generalized Structure Analysis System, Los Alamos National Laboratory Report LAUR-86-748; Los Alamos National Laboratory, Los Alamos, NM, 1994.

[44] Natl. Bur. Stand. (U.S.) Monogr. 1984, 25 20, 38, ICDD (PDF-2) 2006 card no. 34-0394.

[45] M. Yashima, S. Kobayashi, T. Yasui, Crystal structure and the structural disorder of ceria from 40 to $1497^{\circ} \mathrm{C}$, Solid State Ionics 177 (2006) 211-215.

[46] E. Konysheva, J.T.S. Irvine, Transport properties of multi-cations doped cerium oxide, Solid State Ionics 184 (2011) 27-30. 
[47] R.D. Shannon, Revised effective ionic radii and systematic studies of interatomic distances in halides and chalcogenides, Acta Crystallographica Section A 32 (1976) 751-767

[48] S.V. Chavan, A.K. Tyagi, Sub-solidus phase equilibria in $\mathrm{CeO}_{2}-\mathrm{SrO}$ system, Thermochimica Acta 390 (2002) 79-82.

[49] H. Yamamura, E. Katoh, M. Ichikawa, K. Kakinuma, T. Mori, H. Haneda, Multiple doping effect on the electrical conductivity in the $\left(\mathrm{Ce}_{1-x-y} \mathrm{La}_{x} \mathrm{M}_{y}\right) \mathrm{O}_{2-\delta}(\mathrm{M}=\mathrm{Ca}$ Sr) system, Electrochemistry 68 (2000) 455-459.

[50] B.C. Morris, W.R. Flavell, W.C. Mackrodt, M.A. Morris, Lattice parameter changes in the mixed-oxide system $\mathrm{Ce}_{1-x} \mathrm{La}_{x} \mathrm{O}_{2-\delta}$ : a combined experimental and theoretical study, Journal of Materials Chemistry 3 (1993) 1007-1013.

[51] T. Zhang, P. Hing, H. Huang, J. Kilner, Sintering and grain growth of CoO-doped $\mathrm{CeO}_{2}$ ceramics, Journal of the European Ceramic Society 22 (2002) 27-34.

[52] M. Chen, B. Hallstedt, A.N. Grundy, L.J. Gauckler, $\mathrm{CeO}_{2}-\mathrm{CoO}$ phase diagram, Journal of the American Ceramic Society 86 (2003) 1567-1570.

[53] F. Beguin, I. Rashkov, N. Manolova, R. Benoit, R. Erre, S. Delpeux, Fullerene core star-like polymers. 1. Preparation from fullerenes and monoazidopolyehers, European Polymer Journal 34 (1998) 905-915.

[54] Ch. Bichler, H.C. Langowski, M. Bischoff, U. Moosheimer, The substrate-process interface, in: Thin Barrier Film Coating, 39th Annual Technical Conference Proceedings of the Society of Vacuum Coaters, 1996, pp. 378-383.

[55] Database for Surface Spectroscopy http://www.lasurface.com (accessed October 2012).

[56] NIST XPS Database http://srdata.nist.gov/xps/index.htm (accessed October 2012).

[57] D.L. Perry, L. Tsao, H.G. Brittain, X-ray photoelectron and infrared spectroscopic studies of the decarboxylation/oxidation of cerium(Ill) carbonate octahydrate, Journal of Materials Science Letters 3 (1984) 1017-1019.

[58] R.P. Vasquez, X-ray photoelectron spectroscopy study of $\mathrm{Sr}$ and Ba compounds, Journal of Electron Spectroscopy and Related Phenomena 56 (1991) 217-240.

[59] M. Mamak, G.S. Metraux, S. Petrov, N. Coombs, G.A. Ozin, M.A. Green, Lanthanum strontium manganite/yttria-stabilized zirconia nanocomposites derived from a surfactant assisted, co-assembled mesoporous phase, Journal of the American Chemical Society 125 (2003) 5161-5175.

[60] R. Sonntag, S. Neov, V. Kozhukharov, D. Neov, J.E. ten Elshof, Crystal and magnetic structure of substituted lanthanum cobaltites, Physica B 241-243 (1998) 393-396.

[61] E. Konysheva, R. Blackley, J.T.S. Irvine, Conductivity behaviour of composites in the $\mathrm{La}_{0.6} \mathrm{Sr}_{0.4} \mathrm{CoO}_{3 \pm \delta}-\mathrm{CeO}_{2}$ system: function of connectivity and interfacial interactions, Chemistry of Materials 22 (2010) 4700-4711.
[62] D.J. Lam, B.W. Veal, D.E. Ellis, Electronic structure of lanthanum perovskites with 3d transition elements, Physical Review B22 (1980) 5730-5739.

[63] G. Vovk, X. Chen, C.A. Mims, In situ XPS studies of perovskite oxide surfaces under electrochemical polarization, Journal of Physical Chemistry B109 (2005) 2445-2454.

[64] P. Wang, L. Yao, M. Wang, W. Wu, XPS and voltammetric studies on $\mathrm{La}_{1-x} \mathrm{Sr}_{x} \mathrm{CoO}_{3-\delta}$ perovskite oxide electrodes, Journal of Alloys and Compounds 311 (2000) 53-56.

[65] B.J. Tan, K.J. Klabunde, P.M.A. Sherwood, XPS studies of solvated metal atom dispersed catalysts. Evidence for layered cobalt-manganese particles on alumina and silica, Journal of the American Chemical Society 113 (1991) 855-861.

[66] E.A. Lombardo, K. Tanaka, I. Toyoshima, XPS characterization of reduced $\mathrm{LaCoO}_{3}$ perovskite, Journal of Catalysis 80 (1983) 340-349.

[67] K. Tabata, I. Matsumoto, S. Kohiki, Surface characterization and catalytic properties of $\mathrm{La}_{1-x} \mathrm{Sr}_{x} \mathrm{CoO}_{3}$, Journal of Material Science 22 (1987) 1882-1886.

[68] J.C. Dupin, D. Gonbeau, P. Vinatier, A. Levasseur, Systematic XPS studies of metal oxides, hydroxides and peroxides, Physical Chemistry Chemical Physics 2 (2000) 1319-1324.

[69] M.I. Solsulnikov, Y.A. Teterin, X-ray photoelectron studies of Ca, Sr and Ba and their oxides and carbonates, Journal of Electron Spectroscopy and Related Phenomena 59 (1992) 111-126.

[70] P. Kulkarni, S. Mahamuni, S.K. Kulkarni, A.S. Nigavekar, Photoelectron spectroscopic studies of the interface reactions between lead and the high- $\mathrm{T}_{\mathrm{c}}$ $\mathrm{Bi}_{2} \mathrm{Sr}_{2} \mathrm{CaCu}_{2} \mathrm{O}_{8}$ superconductor, Physica C 168 (1990) 104-108.

[71] J.W. Murray, J.G. Dillard, R. Giovanoli, H. Moers, W. Stumm, Oxidation of Mn(II): initial mineralogy, oxidation state and ageing, Geochimica et Cosmochimica Acta 49 (1985) 463-470.

[72] R.P. Grupta, S., K. Sen, Calculation of multiplet structure of core $p$-vacancy levels, Physical Review B10 (1974) 71-77.

[73] C.B. Azzoni, M.C. Mozzati, A. Paleari, V. Massarotti, D. Capsoni, M. Bini, Magnetic Order in Li-Mn Spinels, Zeitschrift für Naturforschung 53A (1998) 693-698.

[74] Y. Teraoka, H.M. Zhang, K. Okamoto, N. Yamazoe, Mixed ionic-electronic conductivity of $\mathrm{La}_{1-x} \mathrm{Sr}_{x} \mathrm{Co}_{1-y} \mathrm{Fe}_{y} \mathrm{O}_{3-\delta}$ perovskite-type oxides, Materials Research Bulletin 23 (1988) 51-58.

[75] H. Ullmann, N. Trofimenko, F. Tietz, D. Stover, A. Ahmad-Khanlou, Correlation between thermal expansion and oxide ion transport in mixed conducting perovskite-type oxides for SOFC cathodes, Solid State Ionics 138 (2000) 79-90.

[76] R.A. De Souza, J.A. Kilner, Oxygen transport in $\mathrm{La}_{1-x} \mathrm{Sr}_{x} \mathrm{Mn}_{1-y} \mathrm{Co}_{y} \mathrm{O}_{3}$ perovskites. Part II. Oxygen surface exchange, Solid State Ionics 126 (1999) 153-161.

[77] O.I. Klyushnikov, V.V.Sal'nikov, N.M. Bogdanovich, X-ray photoelectron spectra of $\mathrm{La}_{0.8-x} \mathrm{Ce}_{x} \mathrm{Sr}_{0.2} \mathrm{MnO}_{3}$, Inorganic Material 38 (2002) 1284-1290. 